\title{
Leuctridae (Plecoptera) of the Pyrenees
}

\author{
G. Vinçon ${ }^{1}$ \\ C. Ravizza ${ }^{2}$
}

Keywords : Plecoptera, Leuctridae, Leuctra, Pachyleuctra, Pyrenees.

A taxonomic and biogeographic study of the Pyrenean Leuctridae is presented. Keys for males and females of 32 Leuctridae species are given.

The male of Pachyleuctra bertrandi Aubert, 1952 is described completely for the first time ; P. ribauti Despax, 1929 is restored as a valid species ; Leuctra ariega Pardo \& Vinçon, 1995, L. garumna Vinçon \& Ravizza, 1996 and L. prima Kempnyi, 1899 are new for the Iberian Peninsula ; L. espanoli Aubert, 1956 is new for the French Fauna.

\section{Les Leuctridae (Plecoptera) des Pyrénées}

Mots-clés : Plecoptera, Leuctridae, Leuctra, Pachyleuctra, Pyrénées.

L'étude taxonomique et biogéographique des Leuctridae des Pyrénées est présentée. Des clés d'identification sont données pour les males et les femelles des 32 espèces de Leuctridae.

Le male de Pachyleuctra bertrandi Aubert, 1952 est décrit complètement pour la première fois ; $P$. ribauti Despax, 1929 est rétablie comme espèce valide ; Leuctra ariega Pardo \& Vinçon, 1995, L. garumna Vinçon \& Ravizza, 1996 et $L$. prima Kempnyi, 1899 sont nouvelles pour la Péninsule Ibérique ; L. espanoli Aubert, 1956 est nouvelle pour la Faune de France.

\section{Introduction}

The family Leuctridae is represented in Europe by three genera, two of them occurring in the Pyrenees : Leuctra Stephens (1836) with a holarctic distribution, and Pachyleuctra Despax (1929), endemic to the Pyrenean chain. The third one, Tyrrhenoleuctra Consiglio (1957), known from Spain, Maghreb, Corsica and Sardinia, does not extend into the Pyrenean chain. Recently, the number of Pyrenean Leuctridae has been raised up to 32 species.

After the complete study of the Alpine Leuctridae (Vinçon \& Ravizza 1998), we give here a compendium of the present knowledge on the taxonomy and the distribution of Pyrenean Leuctridae, providing keys to all

\footnotetext{
1. 38 bis rue du Drac, F38000 Grenoble, F-Grenoble, France

2. Largo O. Murani 4, I-20133 Milano, Italie
}

species in the adult stage, and providing a new and complete revision of the Pyrenean genus Pachyleuctra.-For twenty Pyrenean species, we give original drawings and for the twelve others, also present in the Alpine Fauna, we use our previous drawings (Vinçon \& Ravizza 1998).

\section{History of Pyrenean Leuctridae}

The first Pyrenean Leuctra species were described by Navás $(1917,1919)$. A few years later Despax created the new subgenus Pachyleuctra (Despax 1929a-b, 1930a-b, 1931). In that same period Mosely (1932), in his revision of the European species of the genus Leuctra, described two other new species endemic to the Pyrenees. In 1951 the monograph of the French stoneflies by Despax was published, in which the author discussed the taxonomy of all the Leuctridae inhabiting the Northern slopes of the Pyrenees, giving generic status to Pachyleuctra. In the second half of the 20 th century, several new species of Leuctra as well as 
a new Pachyleuctra species were discovered by Aubert (1952b, 1953, 1954a-b, 1956a-b, 1957, 1962) during his research carried out in several regions of the Iberian Peninsula. Aubert also produced a critical revision of the stonefly species described by Navás (Aubert 1948, 1952a), including a few Leuctridae species from the Pyrenees. A few years later, Berthélemy $(1966,1968)$ analysed the taxonomy, ecology and geographical distribution of Pyrenean stoneflies, providing a major contribution to our knowledge of the Leuctridae. During the last sixteen years, one of us (G. Vinçon) carried out a series of collection trips to both slopes of the Pyrenees. Sampling sites were located in the scarcely explored sections of the chain and many collections were also made in winter. As a result 7 additional new Leuctra species were discovered and described (Zwick \& Vinçon 1993, Vinçon \& Pardo 1994, Pardo \& Vinçon 1995, Vinçon \& Ravizza, 1996).

\section{The Pyrenees}

The Pyrenean chain runs east-west with a length of about $400 \mathrm{~km}$. Its width varies from $100 \mathrm{~km}$ in the central section, where the highest peaks are situated, to $30 \mathrm{~km}$ in the western part (Fig. 1). The French slopes of the Pyrenees are steep and poor in transverse val- leys. In contrast the Spanish slopes fall gradually, and long transversal ridges separate the valleys. The northern slopes (France) are directly subject to precipitation from the Atlantic Ocean, inducing a humid climate, while the southern slopes (Spain), submitted to the Mediterranean influence are much drier. The most important watercourses flowing down the French Pyrenean slopes are the Adour, the Garonne and the Ariège, running into the Atlantic Ocean; the Aude, the Têt and the Tech, flowing into the Mediterranean Sea. On the Spanish slopes, the main rivers are the Aragon, the Gallego, the Cinca and the Segre, all left tributaries of the Ebre River that flows into the Mediterranean.

Table 1 shows the species distribution in the Pyrenees from West to East, according to French and Spanish administrative regions.

\section{Morphological structure of adult Leuc- tridae}

Leuctridae are small to medium sized Plecoptera ; body from brown to dark brown in color. These insects are generally macropterous, and their wings are uniformly dark-colored and wrapped around the abdomen at repose. The second tarsal segment is shorter than the

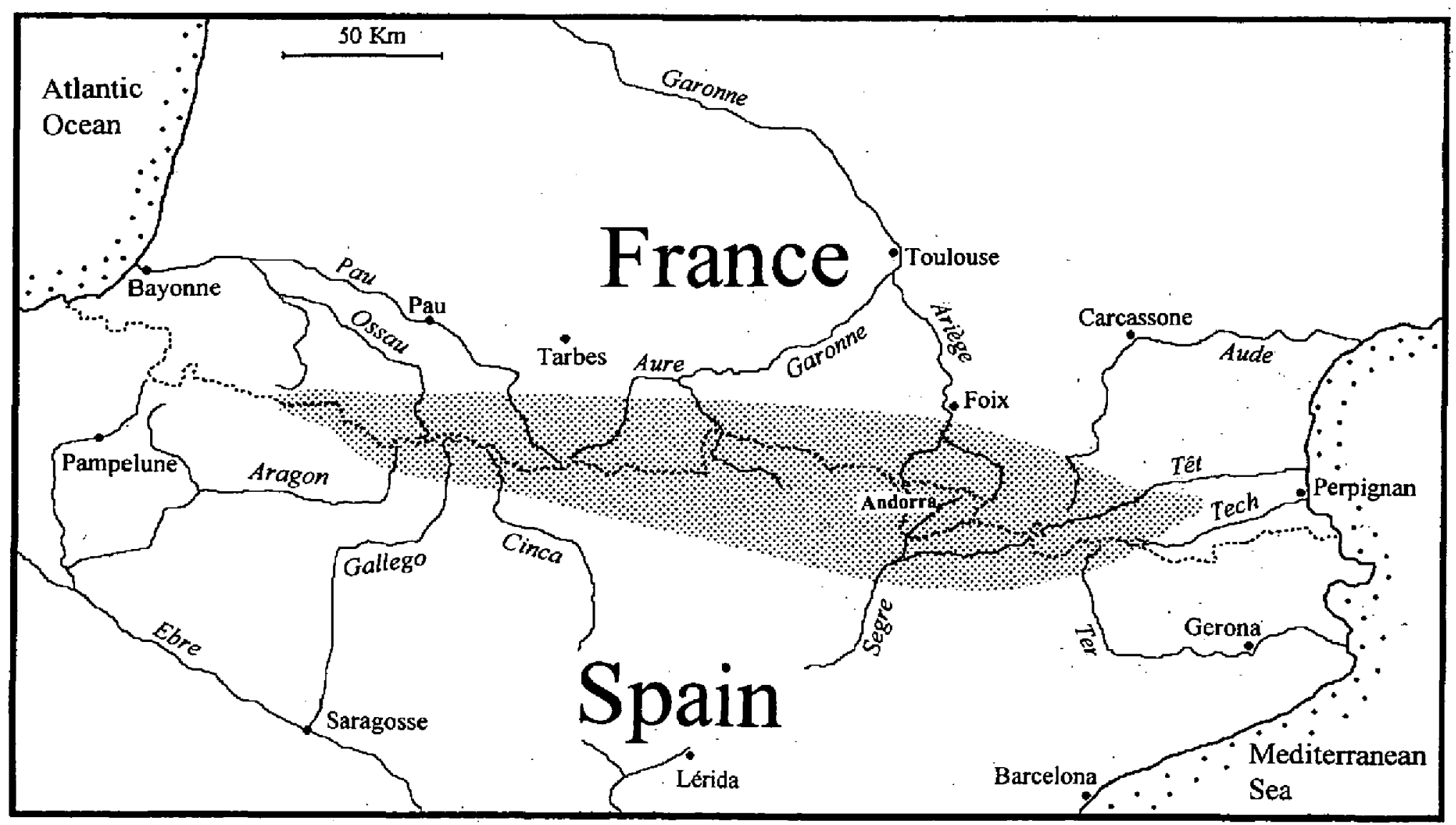

Fig. 1. Map of the Pyrenees. The highest part of the chain (>2000 $\mathrm{m}$ a.s.1.) is shaded.

Fig. 1. Carte des Pyrénées. La partie la plus élevée de la chaîne est grisée (> 2000 m d'altitude). 


\begin{tabular}{|c|c|c|c|c|c|c|c|c|c|c|c|c|}
\hline \multirow[b]{2}{*}{ Leuctridae } & \multicolumn{2}{|c|}{$\begin{array}{l}\text { Western } \\
\text { Pyrenees }\end{array}$} & \multicolumn{5}{|c|}{$\begin{array}{c}\text { Central } \\
\text { Pyrenees }\end{array}$} & \multicolumn{3}{|c|}{$\begin{array}{c}\text { Eastern } \\
\text { Pyrenees }\end{array}$} & \multirow[b]{2}{*}{ Slope } & \multirow[b]{2}{*}{ End. } \\
\hline & $\mathbf{P}-\mathbf{A}$ & NAV & $\mathrm{H}-\mathrm{P}$ & $\mathrm{H}-\mathrm{G}$ & ARA & ARI & AND & CAT & AUD & $\mathrm{P}-\mathrm{O}$ & & \\
\hline \multicolumn{13}{|l|}{ Leuctra } \\
\hline 1. L. albida Kempny & $\cdot$ & & $\cdot$ & $\cdot$ & र & $\cdot$ & & & & & $\mathrm{N}$ & \\
\hline 2. L. alosi Navás & $\cdot$ & - & $\cdot$ & $\cdot$ & • & $\cdot$ & $\cdot$ & $\cdot$ & $\cdot$ & $\cdot$ & NS & \\
\hline 3. L. alticola Despax & $\cdot$ & $\cdot$ & $\cdot$ & $\cdot$ & $\cdot$ & - & $\cdot$ & - & & $\cdot$ & NS & * \\
\hline 4. L. ariega Pardo \& Vincon & & & & & & $\bullet$ & $\cdot$ & & & & NS & * \\
\hline 5. L. aurita Navás & $\cdot$ & $\therefore$ & $\cdot$ & $\cdot$ & $\cdot$ & $\cdot$ & $\therefore$ & $\cdot$ & $\bullet$ & - & NS & \\
\hline 6. L. berthelemyi Zwick \& Vinçon & $\cdot$ & - & & & & & & & & & NS & * \\
\hline 7. L. castillana Aubert & $\dot{.}$ & $\cdot$ & $\cdot$ & - & $\cdot$ & $\cdot$ & $\cdot$ & $\cdot$ & $\cdot$ & $\cdot$ & NS & \\
\hline 8. L. clerguae Vinçon \& Pardo & $\cdot$ & - & & & & & & & & & $\mathrm{N}$ & * \\
\hline 9. L. despaxi Mosely & $\cdot$ & $\cdot$ & $\cdot$ & $\cdot$ & & & & - & & $\cdot$ & NS & \\
\hline 10. L. digitata Kempny & & & $\cdot$ & & & 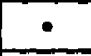 & & $\cdot$ & & $\cdot$ & NS & \\
\hline 11. L. espanoli Aubert & - & $\cdot$ & & & & & & & & & NS & \\
\hline 12. L. fusca (Linné) & $\dot{-}$ & $\cdot$ & $\cdot$ & $\dot{-}$ & $\cdot$ & 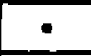 & $\cdot$ & $\cdot$ & $\cdot$ & $\cdot$ & NS & \\
\hline 13. L. garumna Vincon \& Ravizza & & & $\cdot$ & $\cdot$ & & $\cdot$ & $\cdot$ & $\cdot$ & & $\cdot$ & NS & $*$ \\
\hline 14. L. geniculata (Stephens) & - & $\cdot$ & $\bullet$ & $\cdot$ & & $\cdot$ & & $\cdot$ & $\cdot$ & $\cdot$ & NS & \\
\hline 15. L. hexacanthoides Zwick \& Vinçon & $\cdot$ & - & & & & & & & & & NS & * \\
\hline 16. L. hippopus Kempny & $\cdot$ & - & $\cdot$ & $\cdot$ & & $\cdot$ & & $\cdot$ & $\cdot$ & $\cdot$ & NS & \\
\hline 17. L. inermis Kempny & $\cdot$ & - & $\cdot$ & $\dot{-}$ & $\cdot$ & $\cdot$ & $\cdot$ & $\cdot$ & $\cdot$ & $\cdot$ & NS & \\
\hline 18. L. joani Vinçon \& Pardo & $\cdot$ & & & & & & & & & & NS & * \\
\hline 19. L. kempnyi Mosely & $\cdot$ & - & $\cdot$ & & $\cdot$ & & & & & & NS & + \\
\hline 20. L. lamellosa Despax & - & $\cdot$ & $\cdot$ & - & $\cdot$ & - & $\therefore$ & - & $\cdot$ & - & NS & \\
\hline 21. L. leptogaster Aubert & $\cdot$ & & $\cdot$ & 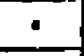 & & $\cdot$ & $\cdot$ & 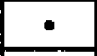 & - & & NS & \\
\hline 22. L. major Brinck & $\cdot$ & & $\div$ & & & - & $\cdot$ & $\bullet$ & & & NS & \\
\hline 23. L. maroccana Aubert & $\cdot$ & $\div$ & & & & & & & & & NS & \\
\hline 24. L. mortoni Kempny & $\cdot$ & & $\cdot$ & $\bullet$ & $\cdot$ & & & & & & NS & \\
\hline 25. L. accitana Despax & & & & $\cdot$ & & & & & & & $\mathbf{N}$ & \\
\hline 26. L. prima Kempny & & & - & $\cdot$ & & $\cdot$ & & $\cdot$ & & $\div$ & NS & \\
\hline 27. L. pseudocylindrica Despax & $\cdot$ & 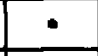 & $\cdot$ & $\cdot$ & - & & & $\div$ & & & NS & + \\
\hline 28. L. rauscheri Aubert & $\cdot$ & $\cdot$ & $\cdot$ & $\cdot$ & $\cdot$ & $\cdot$ & $\cdot$ & $\bullet$ & $\cdot$ & $\cdot$ & NS & \\
\hline 29. L. thomasi Zwick \& Vinçon & & & & & $\therefore$ & $\cdot$ & $\cdot$ & & & & NS & * \\
\hline \multicolumn{13}{|l|}{ Pachyleuctra } \\
\hline 30. P. benllochi (Navás) & $\cdot$ & $*$ & $\cdot$ & - & $\cdot$ & $\therefore$ & - & $\div$ & 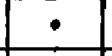 & - & NS & * \\
\hline 31. P. bertrandi Aubert & & & & & & & & $?$ & 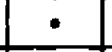 & - & NS & $*$ \\
\hline 32. P. ribauti Despax & & & & $\cdot$ & & & & & 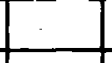 & & $\mathbf{N}$ & $*$ \\
\hline Total species & 24 & 19 & 21 & 20 & 13 & 19 & 14 & 19 & 12 & 16 & & 13 \\
\hline
\end{tabular}

Table 1. Distribution of the species recorded in the Pyrenees. Abbreviations P-A = Pyrénés-Atlantiques $; \mathrm{NAV}=\mathrm{Navarra} ; \mathrm{H}$ $\mathrm{P}=$ Hautes-Pyrénées $; \mathbf{H}-\mathrm{G}=$ Haute-Garonne $; \mathrm{ARA}=$ Aragon $; \mathrm{ARI}=$ Ariège $; \mathrm{AND}=$ Andorra $; \mathrm{CAT}=\mathrm{Cataluña}$; AUD $=$ Aude $; \mathrm{P}-\mathrm{O}=$ Pyrénées-Orientales $;$ End. = Endemic species $; *=$ strictly endemic to the Pyrenees $;+=$ Pyrenean endemic specjes extending to the eastern part of the Cantabrian Cordillera.

Tableau 1. Distribution des espèces de Leuctridae connues des Pyrénées. P-A = Pyrénées-Atlantiques ; NAV = Navarre ; $\mathrm{H}-\mathrm{P}=$ Hautes-Pyrénées $; \mathrm{H}-\mathrm{G}=$ Haute-Garonne $; \mathrm{ARA}=$ Aragon $; \mathrm{ARI}=$ Ariège $; \mathrm{AND}=$ Andorre $; \mathrm{CAT}=\mathrm{Catalogne}$; $\mathrm{AUD}=$ Aude $; \mathrm{P}-\mathrm{O}=$ Pyrénées-Orientales $;$ End $=$ endémique $; *$ endémique stricte des Pyrénées $;+=$ endémique des $\mathrm{Py}-$ rénées légèrement extensive dans la partie est de la Cordillère Cantabrique. 
first and the third. The cerci are one-segmented with sometimes a tiny vestigial second segment at the tip.

The most important morphological characters essential for the identification of Leuctridae species are the sclerotized tergal processes, membranous areas and pigmented spots present in some abdominal male segments, and external genitalia in both sexes.

The terms used in the key, specifically referring to the Leuctra and Pachyleuctra abdomen, are listed below. They are those at present recognised as agreed upon at the First European Symposium on Plecoptera in 1965 (Aubert 1956b, 1957).

- Male abdomen

Each tergite from the 6th to the 8th is provided with an anterior margin also called antecosta (Fig. $2 \mathrm{a}-\mathrm{b}$ $\mathrm{Am}$ ), that is a sclerotized strip, continuous or interrupted in its central section, placed near the base of the terga and the pigmented lateral plates that are often triangular (Fig. 2 a-b Lp). When the anterior margin is continuous (not interrupted in the middle), it may be subrectilinear, curved, or with a more or less deep hollow at its centre. In many species, either from the anterior margin, or from the inner anterior side of the lateral plates, arise one or two sclerotized processes (Fig. 2 $a-b P$ ), the shape and the placement of which constitute some of the most important specific characters. At the centre of the 9th tergum hind margin there is a single or paired pigmented spot (Fig. 2 a St). The vesicle (Fig. $2 \mathrm{c}-\mathrm{d}$ V) is a small lobe, rising backwards from the centre of the basal part of the 9th sternum, sometimes vestigial or even lacking in certain species. This vesicle is a structure used to orientate the abdomen when beating the substratum. The 10 th tergum, smaller than the preceding ones, is crossed in its distal half by a pigmented strip.; its more or-less hollowed hind margin supports the epiproct (Fig. 2 a E). The epiproct is membranous and its shape and size are quite variable from species to species. The paraprocts (Fig. $2 \mathrm{c}-\mathrm{d} \mathrm{L}, \mathrm{Sl}, \mathrm{S}$ ) are paired sclerotized structures composed by a pair of slender processes projected backwards named specilla (S) which form the copulatory organ, and a pair of styles (Sl). At the base of the styles there is a lobe (L) that usually consists of a rounded more or less prominent sclerite. Cerci (Fig. $2 \mathrm{C}$ ) are paired appendages arising from the abdomen tip, composed of a single segment with a minute vestigial second segment. In the genus Leuctra they have no importance in species identification.

\section{- Female abdomen}

The most important taxonomic characters are on the 8th sternum. The subgenital plate (Fig. $2 \mathrm{Sp}$ ) is a mo- dified area of the female 8th sternum frequently divided on its hind margin into two posterior lobes (Fig. 2 e-f Pl). In the genus Leuctra, only a few females are difficult to separate, usually it is sufficient to study the different shapes of the subgenital plate. The spermatheca (Fig. 2 e $\mathrm{Sm}$ ) is shaped like a membranous vesicle, with a sclerotized armature inside. In slightly pigmented specimens, this armature is visible through the transparent 7 th sternum cuticle. Many groups of species show a characteristic type of armature; for instance the species belonging to the fusca, hippopus and inermis group. This structure thus exhibits generally a wide spectrum of variation. On the other hand, the armatures are often very similar in closely related species. For the Pyrenean species, the study of the spermatheca is not indispensable for the identification of the species, but it allows recognition of affinity among certain apparently not closely related species and to clarify to which group they possibly belong.

- Nymphs

We do not provide keys to the nymphs because the taxonomic characters usually proposed for their identification are completely inadequate and often a source of confusion. The nymphs of several species are also unknown.

\section{Groups of species}

Aubert (1946) proposed a separation of the European species of the genus Leuctra into six main groups, and a seventh comprising a few species with uncertain affinities. This grouping, established according to the morphological characters of the male, constitutes a useful method for stressing the different evolutionary lines. Ravizza \& Vinçon (1998) subsequently subdivided some heterogeneous groups into other groups or sub-groups.

«geniculata» group : male with a single sclerotized process on the 6th tergum : L. geniculata.

«boreoni» group : male with two anterior processes on the 6th tergum, and two other lateral processes on the 7 th and 8 th terga. The anterior margin of the 8 th tergum is widely interrupted : L. espanoli.

«berthelemyi» group : male with two sclerotized processes on the 6th and 7th terga. Spermathecal sclerite shaped like an open ring with two thin posterior prolongations : $L$. berthelemyi

«fusca» group : male with two plate-shaped or finger-shaped processes on the 6th tergum (except in $L$. ariega where these processes are vestigial). This group is divided into the following sub-groups. 

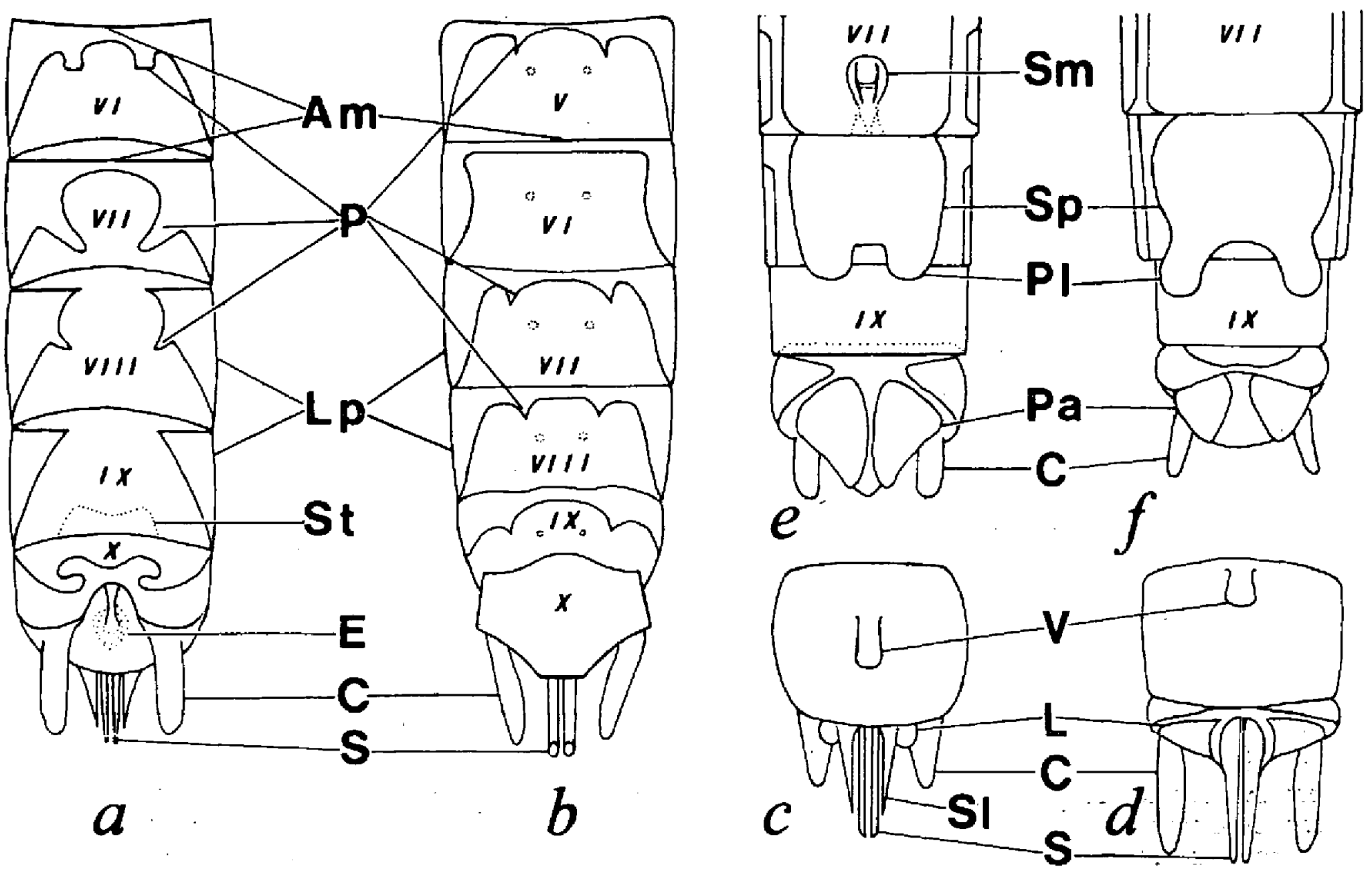

Fig. 2. Tip of a Leuctra abdomen ; male dorsal (a) and ventral (c) views ; female ventral view (e). Tip of a Pachyleuctra abdomen ; male dorsal (b) and ventral (d) views ; female ventral view (f); Abbreviations : Am, anterior margin ; Lp, lateral plates ; C, cercus ; E, epiproct ; L, lateral lobe ; $\mathrm{P}$, sclerotized processes ; $\mathrm{Pa}$, paraproct ; Pl, posterior lobe ; S, specillum ; Sp, subgenital plate ; S1, stylus ; Sm, spermatheca ; St, median spot ; V, vesicle ; V-X, segments.

Fig. 2. Extrémité de l'abdomen d'une Leuctra ; mâle vue dorsale (a) et ventrale (c) ; femelle vue ventrale (e). Extrémité de l'abdomen d'une Pachyleuctra; mâle que dorsale (b) et ventrale (d) ; femelle vue ventrale (f). Abréviations : Am, marge antérieure ; $L p$, bords latéraux ; C, cerque ; E, Epiprocte ; L, lobe latéral ; P, appendices sclérifiés ; Pa, paraprocte ; $P l$, lobe postérieur ; S, spécillum ; Sp, plaque sous-génitale ; Sl, styles ; Sm, spermathèque ; $\mathrm{St}$, tache médiane ; V, vésicule ; V-X, segments.

«fusca» sub-group. Males : styles of the paraprocts tapered, sometimes reduced, or lacking completely. Females : armature of the spermatheca with two longitudinal arms joined at their tips (shaped like a V). $L . d i$ gitata, L. fusca, L. mortoni and L. albida.

«aurita» sub-group. Male : styles of the paraprocts shaped like a thin and curved blade. Females : armature of the spermatheca with thin arms, converging towards their tip (shape sub-oval). L. leptogaster, $L$. major, L. pseudocylindrica, L. castillana, L. lamellosa, $L$. aurita, $L$. alticola, $L$. despaxi, $L$. ariega and $L$. hexacanthoides.

«hippopus» group : male with two processes on the 8th tergum only, or sometimes lacking any process. In the Pyrenees, this group comprises the following three sub-groups. "prima" sub-group. Male with a single plate-shaped process on the 8th tergum. $L$. prima, $L$. joani and $L$. clerguae.

«hippopus» sub-group. Male with two processes either completely separated, or joined at their apices by a thin sclerotized crossbar, on the 8th tergum. L. hippopus.

"occitana» sub-group. Male with membranous terga from the 6th to the 9th segment, having two processes either on the 8th tergum only, or, sometimes, absent. Paraprocts plough shaped in lateral view. In the female, the armature of the spermatheca has two anteroposterior teeth shaped as a half moon, and joined to each other by a central arch. L. occitana, L. thomasi and L. maroccana.

«inermis» group : the male lacks any process on all the abdominal terga, the lateral lobes of the paraprocts 
are well protruding and project outwards the base of the styles. The female possesses an accessory receptaculum, on the dorsal side of the vagina (Zwick 1973, p. 172 , fig. e). L. inermis, L. alosi, $L$. rauscheri, L. kempnyi and L. garumna.

\section{Key to Genera}

Though the genus Tyrrhenoleuctra is not represented in the Pyrenees, in this key we mention the three European Leuctridae genera.

\subsection{Males}

1 Prosternum with a single median sclerotization. Epiproct shaped like a membranous lobe.

1' Prosternum and eusternum divided into two sclerites, the presternum and the basisternum separated by a thin membranous V-shaped strip. Male 10th tergum well developed. Epiproct formed by a tube, ventrally open, appearing subtriangular in posteroventral view and pearshaped in lateral view. Base of the paraprocts constituted by a transverse sclerotized belt; the long and slender paired specilla and styles project backwards from this sclerotized belt. The distal third of these processes is sheathed into the epiproct

2 Male epiproct placed at the tip of a stalk arising from the centre of the 10th tergum hind margin. 9th sternum vesicle, when present, clearly separated from the 9th sternum hind margin. Paraprocts sclerotized, composed by styles, specilla and lateral lobes. Tergal processes on one, two or three terga, or completely lacking

2' Male epiproct reduced to a short membranous lobe usually hidden under a 10th tergum protrusion. 9 th sternum vesicle placed close to the 10th sternum hind margin. Specilla strong, well developed, styles lacking. Paired processes on the $5,7,8$ and 9 terga

\subsection{Females}

1 Sterna provided with a pigmented strip in the middle. 10th sternum membranous in the middle

\section{Tyrrhenoleuctra}

Pachyleuctra
1' Sterna membranous in the middle. 8th sternum provided with a median subgenital plate

2 Sterna almost completely pigmented except a median membra. nous longitudinal strip. 10th sternum continuous

2' Sterna mostly membranous pigmented only at their sides. 10th sternum discontinuous in the middle

Leuctra

\section{Key of the genus Leuctra}

\subsection{Males}

1 Single or paired sclerotized processes on the 6th, 7th or 8th terga, arising backwards either from the anterior margin or from the inner margin of the lateral plates

1' No tergal processes on any of the abdominal segments (inermis group, and $L$. maroccana)

2 (1) A single long and strong median process, bayonet-shaped, on the 8th tergum (Fig. 3 a). Antennae with a whorl of long hairs around the apex of each segment (Fig. $3 \mathrm{e}$ )

2' No single median process on the 8th tergum. Antennae without a whorl of long hairs around the apex of each segment (Fig. 4 h)

3 (2') Processes of the 8th tergum long, finger-shaped, strongly erect in lateral view. Two small processes on the 6th and 7th terga (Fig. 4 a)

3' Processes of the 8th tergum different in shape and not strongly erect in lateral view

4 (2') Two small subtriangular processes on the anterior margin of the 6 th and 7 th terga. 9 th , sternum vesicle small. Brachypterous (Fig. 5 a)

4' No subtriangular processes on the anterior margin of the 6th and 7 th terga

5 (4') Single or paired processes on the 8 th tergum only (hippopus group)

5' Paired processes on one, two or three terga, always including the 6th segment (these processes are strongly reduced in $L$. ariega) (fusca group) 

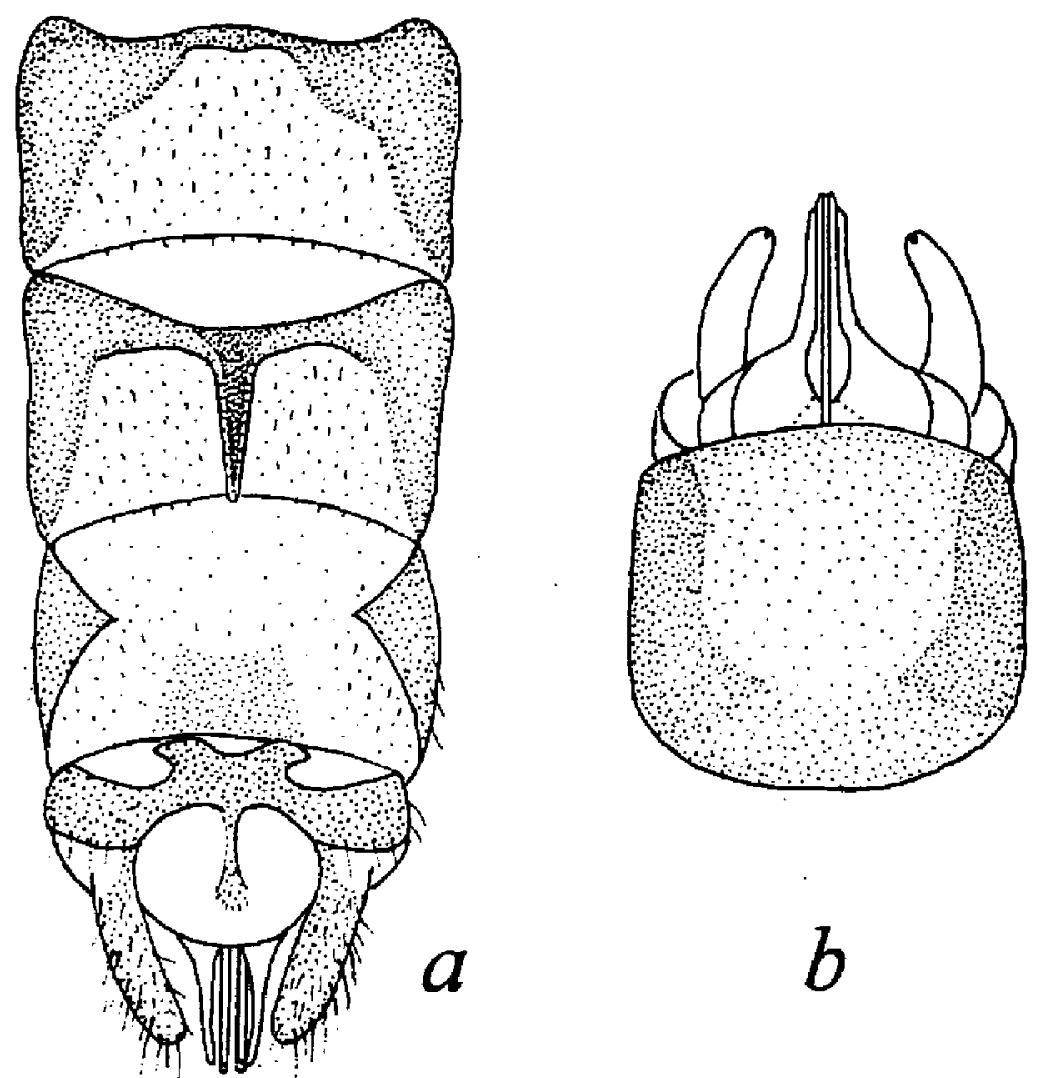

$b$
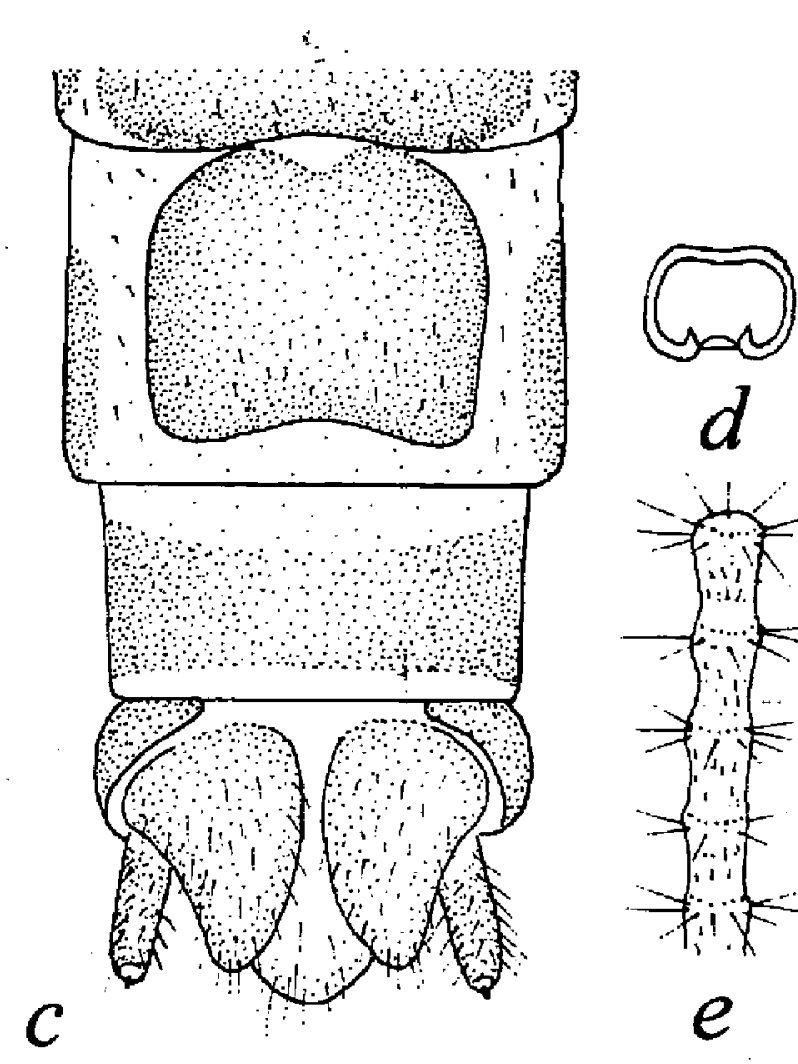

Fig. 3. Leuctra geniculata : tip of the malc abdomen in dorsal (a) and ventral (b) view; tip of the female abdomen in ventral view (c); spermatheca in ventral view (d) ; basal article of the antenna (e).

Fig. 3. Leuctra geniculata: extrémité de l'abdomen du mâle en vue dorsale (a) et ventrale (b) ; extrémité de l'abdomen de la femelle en vue ventrale (c); spermathèque en vue ventrale (d); article basal de l'antenne (e).

6 (5') 8th tergum with two sclerotized processes which are well developed or reduced to small sclerotized points (Fig. 6,7)

6. 8th tergum without any sclerotized processes (Fig. 8, 9) or with two pigmented finger-shaped expansions (Fig. $9 \mathrm{i}, \mathrm{m}$ )

7 (6) Processes of the 8th tergum well developed (Fig. 6)

7' Processes of the 8th tergum reduced to small sclerotized points (Fig. 7)

8 (7) 8th tergum with two long finger-shaped processes arising from the inner margin of the 1ateral plates

$8^{\prime}$ 8th tergum with two rounded processes arising from the anterior margin of the segment, postero-median portion of tergum occupied by large pigmented spot. Two rounded processes on the 6th and 7th terga. Anterior margin of the 9 th tergum medially connected to a large bellshaped spot (Fig. 6 i)
9 (8) 6th tergum with two vestigial processes arising from the anterior margin of the segment ; 7 th tergum without any processes ; 8th tergum with two long fingershaped processes (Fig. 6 e)

9' 6th tergum with two large rectangular processes arising from the anterior margin of the segment ; 7 th tergum with two small processes arising from the inner margin of the lateral plates; 8 th tergum with two long finger-shaped processes (Fig. 6 a)

10 (7) Processes of the 7th tergum strongly reduced compared to those of the 6th tergum

10' Processes of the 7th tergum well developed, similar to those of the 6th tergum but much widely separated (Fig. 7 p). Ventral vesicle well developed (Fig. 7 q)

11 (10) Styles of the paraprocts sickle-shaped in lateral view (Fig. $7 \mathrm{~m}$ )

11' Styles of the paraprocts not sickleshaped in lateral view (Fig. $7 \mathrm{c}, \mathrm{h}$ )

despaxi

alticola

castillana 

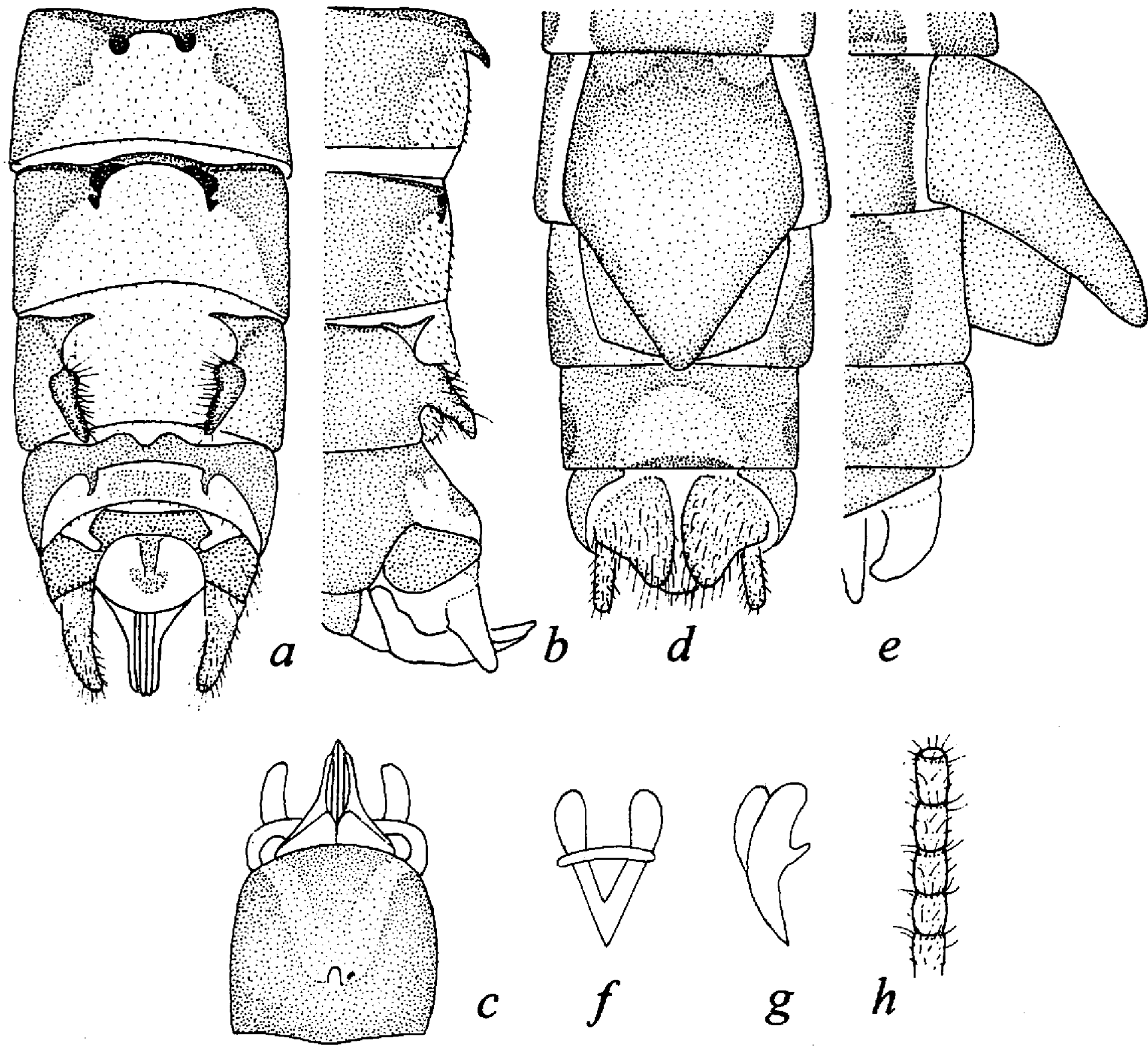

Fig. 4. Leuctra espanoli : tip of the male abdomen in dorsal (a), lateral (b) and ventral (c) view ; tip of the female abdomen in ventral (d) and lateral (e) view ; spermatheca in ventral (f) and lateral (g) view ; basal article of the antenna (h).

Fig. 4. Leuctra espanoli : extrémité de l'abdomen du mâle en vue dorsale (a), latérale (b) et ventrale (c) ; extrémité de l'abdomen de la femelle en vue ventrale (d) et latérale (e) ; spermathèque en vue ventrale (f) et latérale (g) ; article basal de l'antenne (h).

12 (11') Ventral vesicle well developed (Fig. 7 b). Processes of the 6th tergum rather small (Fig. 7 a)

12' Ventral vesicle strongly reduced (Fig. $7 \mathrm{~g}$ ). Processes of the 6th tergum rather wide (Fig. $7 \mathrm{f}$ )

13 (6') Ventral vesicle long and pedunculated (Fig. 8)

13' Ventral vesicle strongly reduced or lacking (Fig. 9)

14 (13) Processes of 7th tergum well developed, almost as big as those of the 6th tergum
14' Processes of 7th tergum strongly reduced, much smaller than those of the 6 th tergum. Median part of the 8th tergum fully membranous (Fig. 8 i, j) lamellosa

14
5 (14) Processes of the 6th tergum pseudocylindrica separated by a space twice to three times wider than the width of one of them; processes of the 7th tergum widely separated ; 8th tergum fully membranous medially (Fig. 8 a, b) 

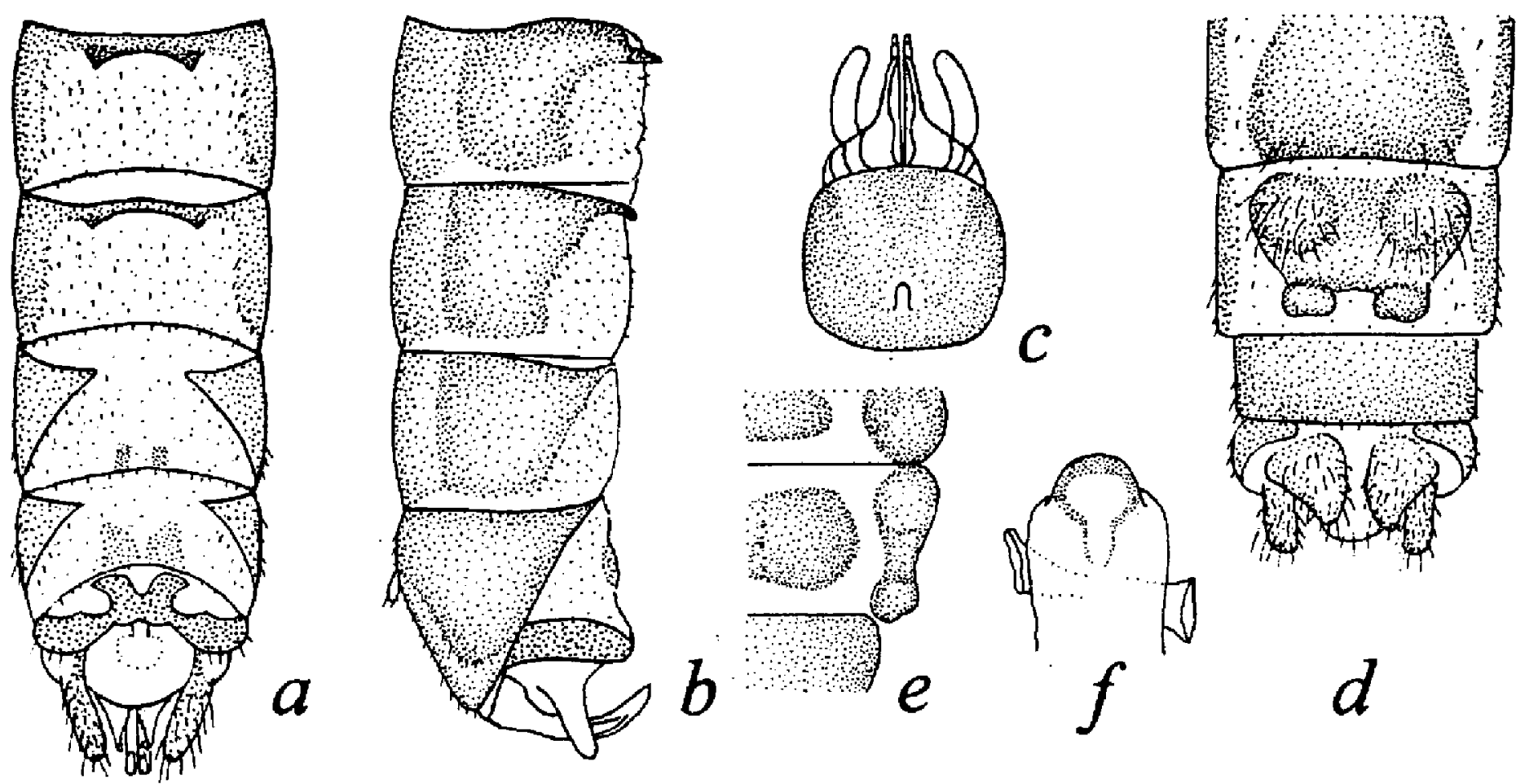

Fig. 5. Leuctra berthelemyi : tip of the male abdomen in dorsal (a), lateral (b) and ventral (c) view ; tip of the female abdomen in ventral view (d); female subgenital plate in lateral view (e); spermatheca in ventral view (f).

Fig. 5. Leuctra berthelemyi : extrémité de l'abdomen du mâle en vue dorsale (a), latérale (b) et ventrale (c) ; extrémité de l'abdomen de la femelle en vue ventrale (d) ; plaque sous-génitale de la femelle en vue latérale (e) ; spermathèque en vue ventrale (f).

15' Processes of the 6th tergum separated by a space about as wide as the width of one of them; processes of the 7th tergum directed upwards and inwards, with their apices opposite to each other; 8th tergum with an oval pigmented spot-medially (Fig. 8 e, f)

16 (13') Anterior margin of the 7th tergum interrupted in the middle. Paraprocts styles not reduced (slightly shorter than the specilla)

16. Anterior margin of the 7th tergum not interrupted in the middle (Fig. $9 \mathrm{~m}$ ). Paraprocts styles strongly reduced (Fig. 9 n). Paired processes of the 7 th tergum similar to those of the 6th tergum but slightly smaller. 8 th tergum with paired finger-shaped pigmented expansions, arising from the inner margin of the lateral plates and converging backwards. Ventral vesicle very small (Fig. $9 \mathrm{~m}, \mathrm{n}$ )

albida

17 (16) Processes of the 6th tergum short, quadrate or subtrapezoidal
17' Processes of the 6th tergum finger-shaped, arising centrally from the anterior margin. Processes of the 7th tergum arising from the inner margin of the lateral plates and directed more or less horizontally inwards across the tergum, so that their apices are opposite to each other ; 8 th tergum with two triangular pigmented spots (Fig. 9 a, b)

18 (17) Ventral vesicle present ; processes of the 6th tergum strong and thick, directed backwards and slightly convergent; anterior margin of the 8th tergum discontinuous in the middle, with a single pigmented spot near the hind margin (Fig. 9 e, f)

18' Ventral vesicle absent or vestigial; processes of the 7 th tergum very narrow, rectangular, converging backwards; 8th tergum with paired finger-shaped pigmented expansions, arising from the inner margin of the lateral plates and converging backwards (Fig. $9 \mathrm{i}, \mathrm{j}$ ) digitata

fusca

mortoni 

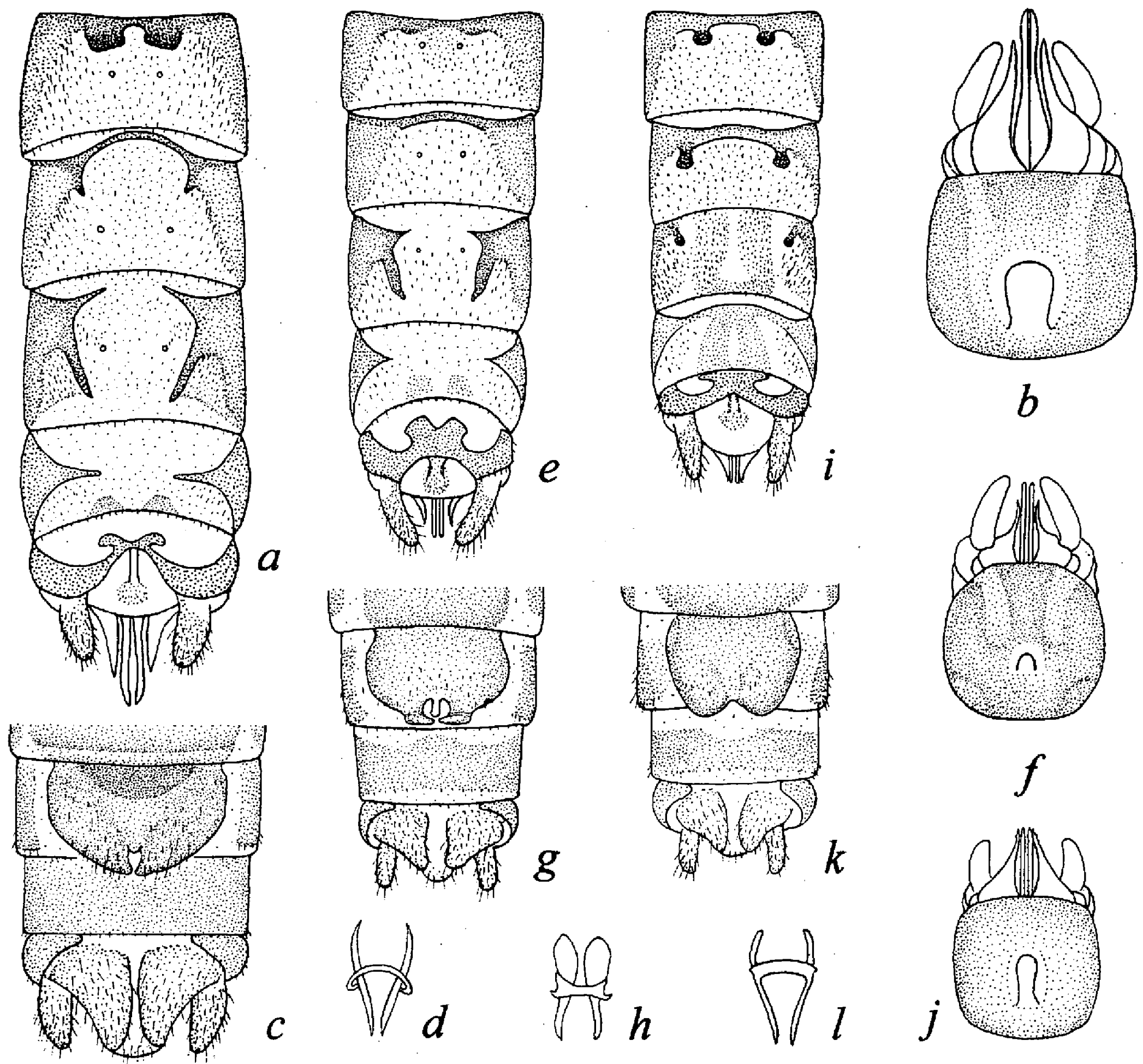

Fig. 6. Leuctra despaxi : tip of the male abdomen in dorsal (a) and ventral (b) view; tip of the female abdomen in ventral view (c) ; spermatheca in ventral view (d). L. ariega : tip of the male abdomen in dorsal (e) and ventral (f) view ; tip of the female abdomen in ventral view (g) ; spermatheca in ventral view (h). L hexacanthoides : tip of the male abdomen in dorsal (i) and ventral (j) view ; tip of the female abdomen in ventral view (k); spermatheca in ventral view (l).

Fig. 6. Leuctra despaxi : extrémité de l'abdomen du mâle en vue dorsale (a) et ventrale (b) ; extrémité de l'abdomen de la femelle en vue ventrale (c) ; spermathèque en vue ventrale (d). L. ariega : extrémité de l'abdomen du mâle en vue dorsale (e) et ventrale (f) ; extrémité de l'abdomen de la femelle en vue ventrale $(\mathrm{g})$; spermathèque en vue ventrale $(\mathrm{h})$. L. hexacanthoides : extrémité de l'abdomen du mâle en vue dorsale (i) et ventrale $(\mathrm{j})$; extrémité de l'abdomen de la femelle en vue ventrale ( $\mathrm{k})$; spermathèque en vue ventrale (1). 

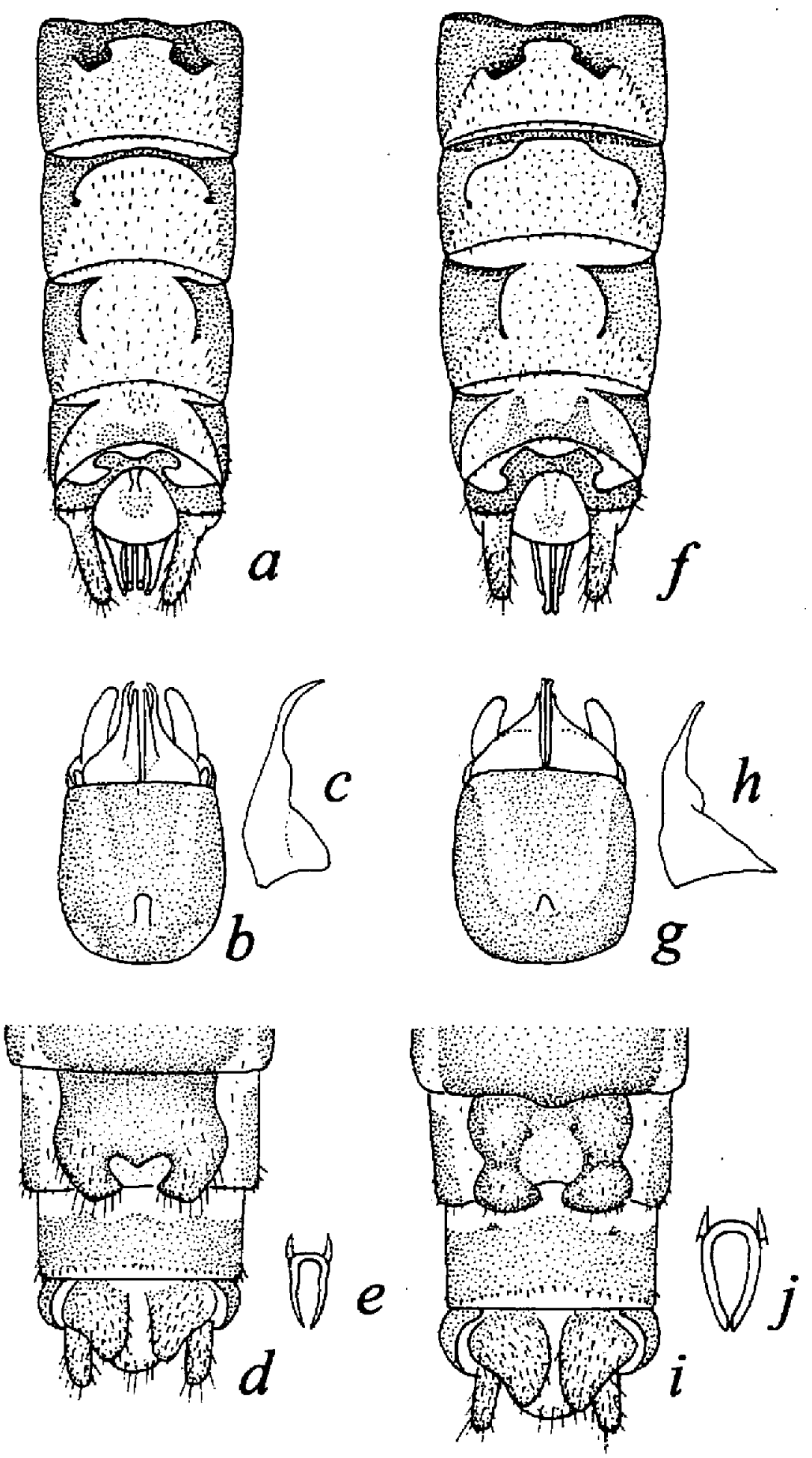
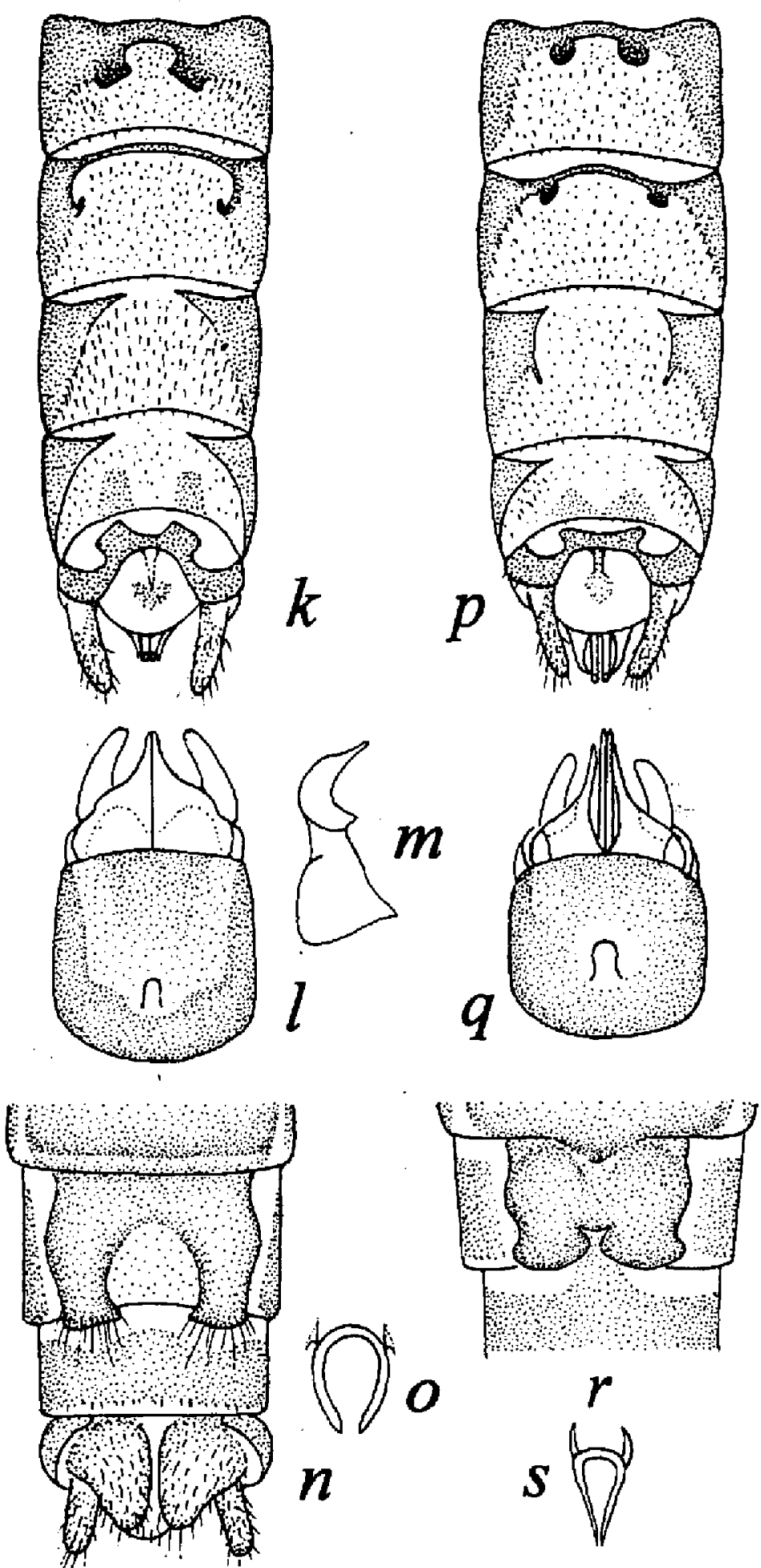

Fig. 7. Leuctra aurita :ttip of the male abdomen in dorsal (a) and ventral (b) view; styli in lateral view (c) ; tip of the female abdomen in ventral view (d) ; spermatheca in ventral view (e). L. lamellosa : tip of the male abdomen in dorsal (f) and ventral ( $\mathrm{g}$ ) view ; styli in lateral view (h); tip of the female abdomen in ventral view (i) ; spermatheca in ventral view (j). L. castillana : tip of the male abdomen in dorsal $(\mathrm{k})$ and ventral (l) view ; styli in lateral view $(\mathrm{m})$; tip of the female abdomen in ventral view (n) ; spermatheca in ventral view (o). L alticola : tip of the male abdomen in dorsal (p) and ventral (q) view ; female subgenital plate in ventral view (r); spermatheca in ventral view (s).

Fig. 7. Leuctra aurita: extrémité de l'abdomen du mâle en vue dorsale (a) et ventrale (b) ; styles en vue latérale (c) ; extrémité de l'abdomen de la femelle en vue ventrale (d) ; spermathèque en vue ventrale (e). L. lamellosa : extrémité de l'abdomen du mâle en vue dorsale $(\mathrm{f})$ et ventrale $(\mathrm{g})$; styles en vue latérale $(\mathrm{h})$; extrémité de l'abdomen de la femelle en vue ventrale (i) ; spermathèque en vue ventrale (j). L. castillana : extrémité de l'abdomen du mâle en vue dorsale (k) et ventrale (l) ; styles en vue latérale (m); extrémité de l'abdómen de la femelle en vue ventrale (n); spermathèque en vue ventrale (o). L. alticola : extrémité de l'abdomen du 

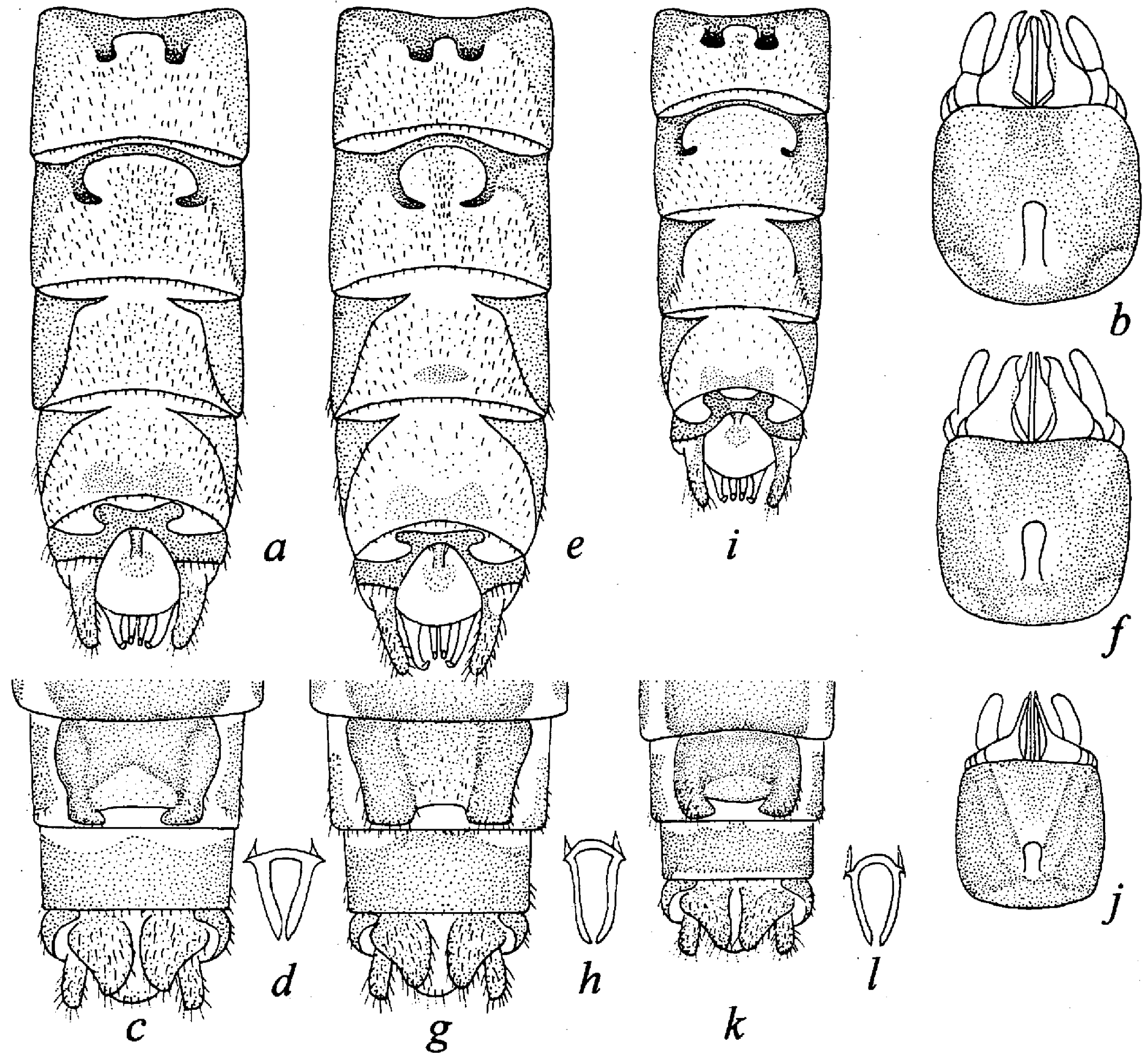

Fig. 8. Leuctra major : tip of the male abdomen in dorsal (a) and ventral (b) view; tip of the female abdomen in ventral view (c) ; spermatheca in ventral view (d). L. leptogaster : tip of the male abdomen in dorsal (e) and ventral (f) view ; tip of the female abdomen in ventral view (g) ; spermatheca in ventral view (h). L. pseudocylindrica : tip of the male abdomen in dorsal (i) and ventral (j) view; tip of the female abdomen in ventral view (k); spermatheca in ventral view (l).

Fig. 8. Leuctra major : extrémité de l'abdomen du mâle en vue dorsale (a) et ventrale (b) ; extrémité de l'abdomen de la femelle en vue ventrale (c) ; spermathèque èn vue ventrale (d). L. leptogaster : extrémité de l'abdomen du mâle en vue dorsale (e) et ventrale (f) ; extrémité de l'abdomen de la femelle en vue ventrale $(\mathrm{g})$; spermathèque en vue ventrale (h). L. pseudocylindrica: extrémité de l'abdomen du mâle en vue dorsale (i) et ventrale (j) ; extrémité de l'abdomen de la femelle en vue ventrale (k) ; spermathèque en vue ventrale (l). 

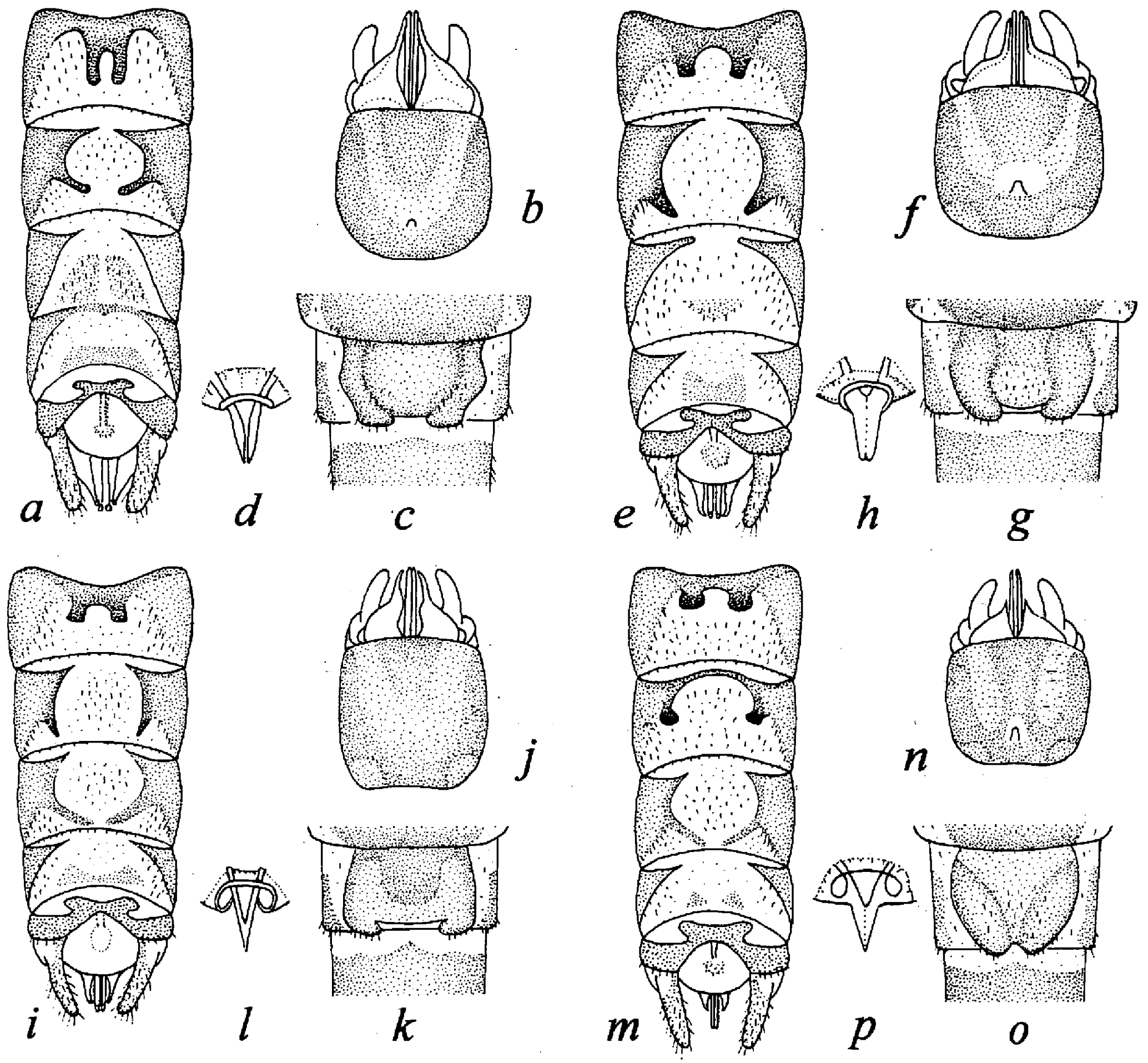

Fig. 9. Leuctra digitata : tip of the male abdomen in dorsal (a) and ventral (b) view ; female subgenital plate in ventral view (c) ; spermatheca in ventral view (d). L fusca : tip of the male abdomen in dorsal (e) and ventral (f) view ; female subgenital plate in ventral view (g) ; spermatheca in ventral view (h). L mortoni : tip of the male abdomen in dorsal (i) and ventral (j) view ; female subgenital plate in ventral view (k) ; spermatheca in ventral view (1). L. albida : tip of the male abdomen in dorsal (m) and ventral (n) view ; female subgenital plate in ventral view (o); spematheca in ventral view (p).

Fig. 9. Leuctra digitata : extrémité de l'abdomen du mâle en vue dorsale (a) et ventrale (b) ; plaque sous-génitale de la femelle en vue ventrale (c); spermathèque en vue ventrale (d). L. fusca : extrémité de l'abdomen du mâle en vue dorsale (e) et ventrale (f); plaque sous-génitale de la femelle en vue ventrale $(\mathrm{g})$; spermathèque en vue ventrale $(\mathrm{h})$. L. mortoni : extrémité de l'abdomen du mâle en vue dorsale (i) et ventrale (j) ; plaque sous-génitale de la femelle en vue ventrale (k) ; spermathèque en vue ventrale (1). $L$. albida : extrémité de l'abdomen du mâle en vue dorsale (m) et ventrale (n); plaque sous-génitale de la femelle en vue ventrale (o) ; spermathèque en vue ventrale ( $\mathrm{p}$ ). 
19 (5) 8th tergum with a median plate-shaped process, provided with two small teeth (Fig. 10)

$19^{\prime}$ 8th tergum with two median processes arising from the lateral plates and completely separated by the median membranous area (Fig. 11)

20 (19) Macropterous or micropterous species. Process of the 8th tergum ending into two well developed triangular teeth

20' Apterous species. Process of the 8 th tergum ending into two hardly visible teeth ; 9 th tergum with a median pentagonal spot. Ventral vesicle lacking (Fig. 10 $\mathrm{i}, \mathrm{j})$

21 (20) Macropterous species. 9th tergum with two pigmented spots, connected to each other. Ventral vesicle long and pedunculated (Fig. $10 \mathrm{a}, \mathrm{b}$ )

21' Micropterous species. 9th tergum with two pigmented spots, separated by a space as wide as the width of one of them. Ventral vesicle strongly reduced (Fig. $10 \mathrm{e}$, f)

22 (19') Ventral vesicle well developed. 6th tergum completely pigmented

22' Ventral vesicle lacking. (Fig. 11 j). 6 th and 7 th terga medially membranous, with their anterior margin not interrupted in the middle ; 8 th tergum with two thin sclerotized processes lying along the lateral edges. 9th tergum with two oval spots separated by a space as wide as the wide of one of them (Fig. 11 $i, j$ )

23 (22) Anterior margin of the 7th tergum not interrupted in the middle ; processes of the 8 th tergum strong, finger-shaped; median spot of the 9th tergum subtrapezoidal. Epiproct large, racket-shaped. Ventral vesicle short (Fig. $11 \mathrm{a}, \mathrm{b}$ )

23' Anterior margin of the 7th tergum interrupted in the middle; processes of the 8th tergum thin and small ; median spot of the 9 th tergum anteriorly notched. Epiproct small, triangular. Ventral vesicle long and pedunculated (Fig. $11 \mathrm{e}, \mathrm{f}$ )
24 (1') 6th tergum medially membranous; 7 th and 8th terga with two pigmented expansions arising from the inner margin of the lateral plates and converging backwards ; lateral lobes narrow, joined to the base of the styles along all their inner margin (Fig. $11 \mathrm{~m}, \mathrm{n}$ )

maroccana

24' 6th tergum completely pigmented ; 7 th and 8 th terga without any pigmented expansions ; lateral lobes projecting outside and joined to the base of the styles only in the basal portion of their inner margin (Fig. 12, 13) (inermis group)

clerguae $25\left(24^{\prime}\right)$ Lateral lobes of the paraprocts longer than wide

prima

25' Lateral lobes of the paraprocts as long as wide (Fig. $12 \mathrm{f}$ ) ; 7th tergum completely pigmented except near the posterior margin; 9th tergum with a sub-rectangular pigmented spot, slightly notched anteriorly; hind margin of the 10th tergum with a shallow median notch. Styles of the paraprocts with thick apex (Fig. $12 \mathrm{e}$, f)

2326 (25) Anterior margin of the 7th tergum entire (Fig. 13)

alosi

27

26' Anterior margin of the 7th tergum interrupted in the middle ; anterior margin of the 8th tergum interrupted and curved along the lateral plates, forming a blunt angle ; 9 th tergum with a $\mathrm{V}$-shaped pigmented spot ; hind margin of the 10th tergum with a ve-

occitana ry shallow median notch (Fig. 12 a, b)

27 (26) 7 th tergum with membranous median area

inermis

28

27' 7 th tergum pigmented except near the posterior margin ; hind margin of the 10th tergum with a median, triangular notch (Fig. 13

hippopus $\mathrm{a}, \mathrm{b})$

28 (27) On the 6th tergum, the narrow sclerotized strip of the anterior margin extends for half the segment width ; lateral margins of the 8th tergum rectilinear; median pigmented spot of the 9th tergum with shallow anterior notch (Fig. 13 f, g)

rauscheri

thomasi 

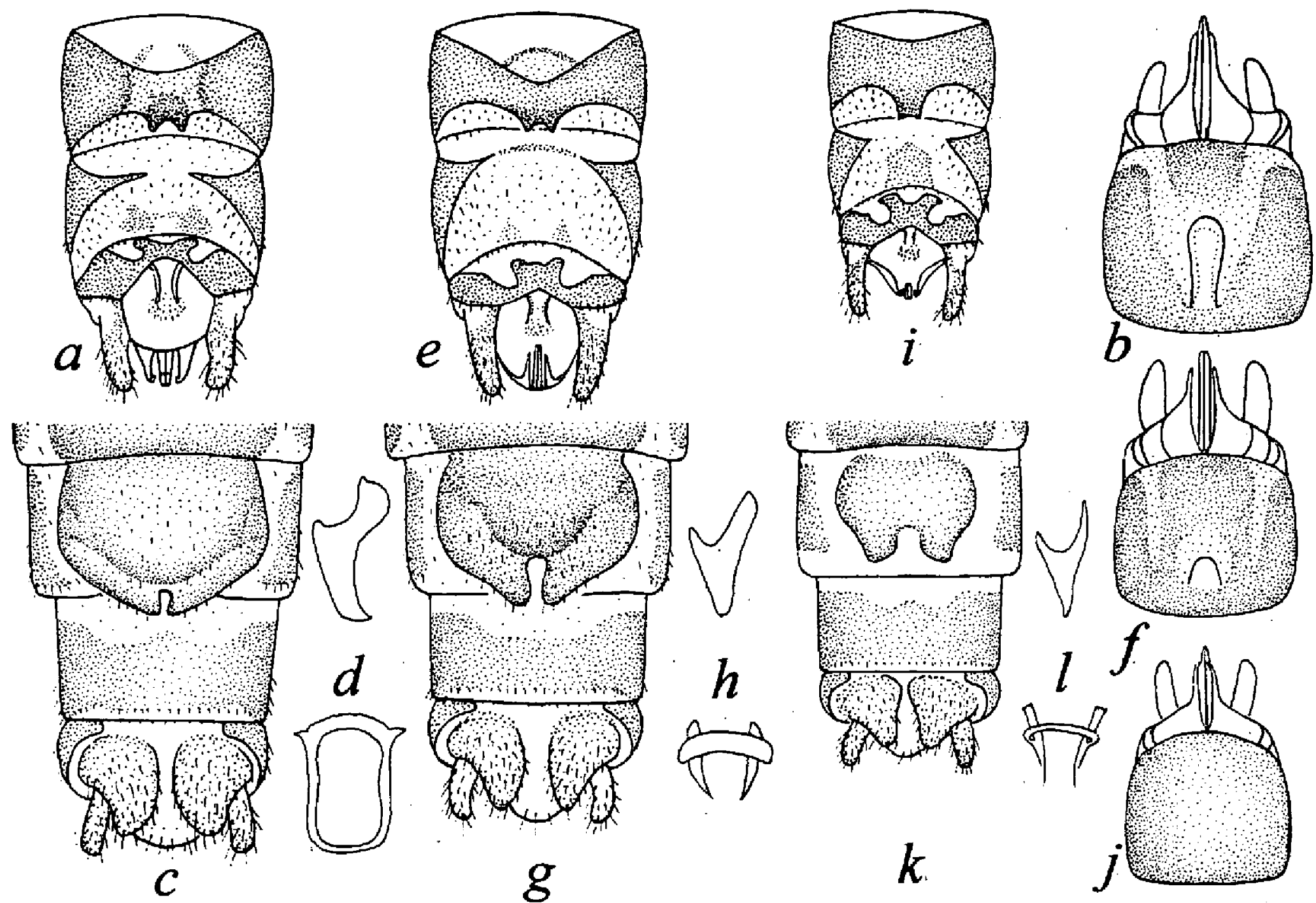

Fig. 10. Leuctra prima : tip of the male abdomen in dorsal (a) and ventral (b) view ; tip of the female abdomen in ventral view (c); spermatheca in ventral and lateral view (d). L joani : tip of the male abdomen in dorsal (e) and ventral (f) view; tip of the female abdomen in ventral view $(\mathrm{g})$; spermatheca in ventral and lateral view $(\mathrm{h})$. L. clerguae : tip of the male abdomen in dorsal (i) and ventral (j) view ; tip of the female abdomen in ventral view (k); spermatheca in ventral and lateral view (l).

Fig. 10. Leuctra prima : extrémité de l'abdomen du mâle en vue dorsale (a) et ventrale (b) ; extrémité de l'abdomen de la femelle en vue ventrale (c) ; spermathèque en vue ventrale et latérale (d). L. joani : extrémité de l'abdomen du mâle en vue dorsale (e) et ventrale (f) ; extrémité de l'abdomen de la femelle en vue ventrale $(\mathrm{g})$; spermathèque en vue ventrale et latérale (h). L. clerguae : extrémité de l'abdomen du mâle en vue dorsale (i) et ventrale (j); extrémité de l'abdomen de la femelle en vue ventrale (k); spermathèque en vue ventrale et latérale (1).

$\mathbf{2 8}^{\prime}$ On the 6th tergum, the narrow sclerotized strip of the anterior margin extends for one third of the segment width ; lateral margins of the 8th tergum rounded; median pigmented spot of the 9th tergum with deep anterior notch (Fig. $13 \mathrm{k}$, 1)

garumna

\subsection{Females}

1 Sternite VII with a long prominent triangular expansion covering the median part of the subgenital plate (Fig. 4 c, d)

espanoli :

1' Sternite VII without any triangular expansion
2 (1') Two lateral bulges covered with long hairs on the anterior part of the subgenital plate. Lobes shorter than wide, separated by a space about as wide as the width of one of them (Fig. 5 $d, e, f)$

2' No lateral bulges on the anterior part of the subgenital plate

berthelemyi

3 (2') Subgenital plate without any posterior lobes

3' Subgenital plate with two posterior lobes

4 (3) Subgenital plate almost quadrangular, without any median narrowing. Antennae with a whorl of long hairs around the apex of each segment (Fig. 3 c, d, e) geniculata 

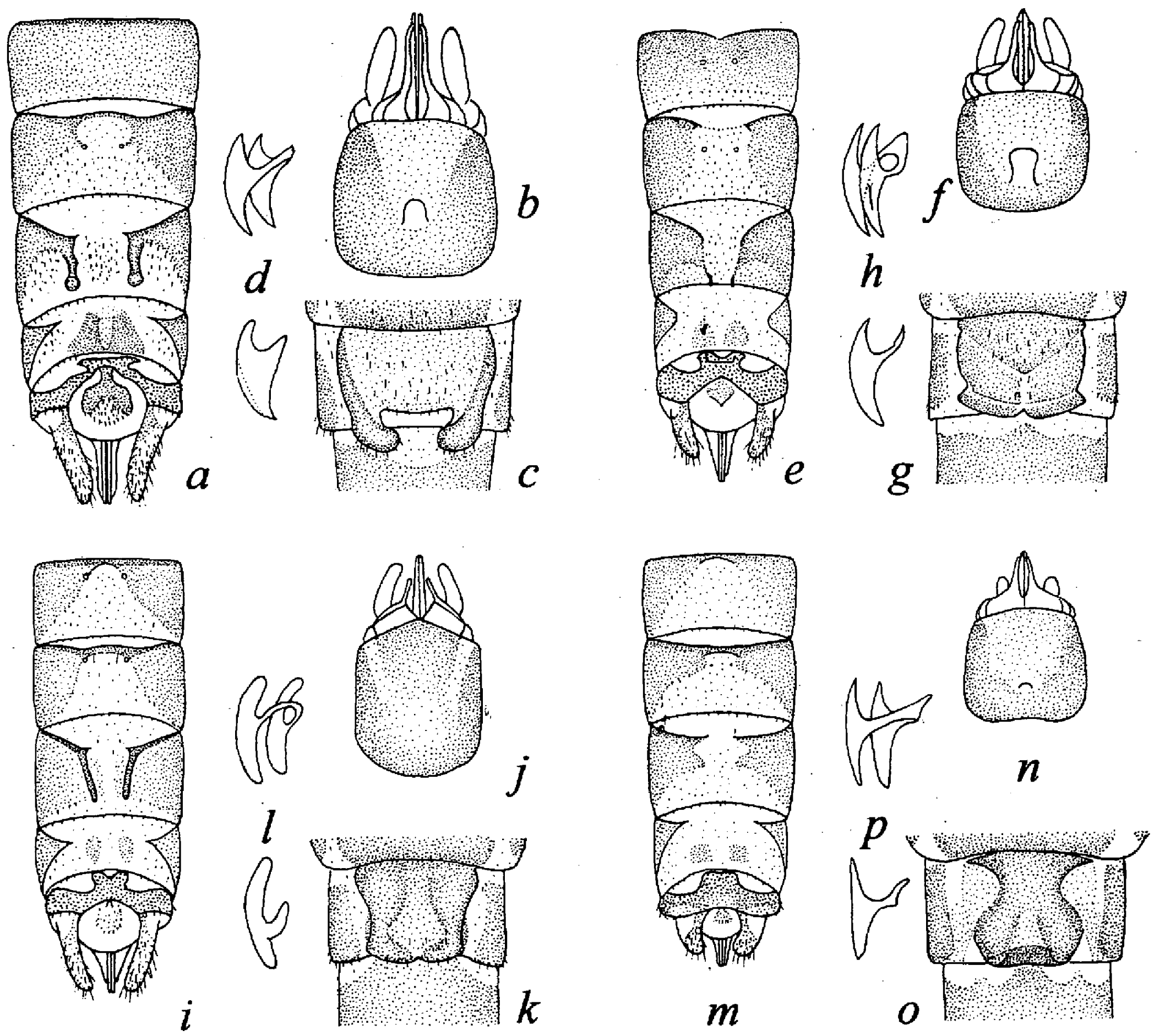

Fig. 11. Leuctra hippopus : tip of the male abdomen in dorsal (a) and ventral (b) view ; female subgenital plate in ventral (c) view ; spermatheca in lateral and semi-lateral view (d). L. thomasi : tip of the male abdomen in dorsal (e) and ventral (f) view ; female subgenital plate in ventral view (g) ; spermatheca in lateral and semi-lateral view (h). L. occitana : tip of the male abdomen in dorsal (i) and ventral (j) view ; female subgenital plate in ventral view (k); spermatheca in lateral and semi-lateral view (l). L. marrocana : tip of the male abdomen in dorsal $(\mathrm{m})$ and ventral $(\mathrm{n})$ view ; female subgenital plate in ventral view $(\mathrm{o})$; spermatheca in lateral and semi-lateral view (p).

Fig. 11. Leuctra hippopus : extrémité de l'abdomen du mâle en vue dorsale (a) et ventrale (b) ; extrémité de l'abdomen de la femelle en vue ventrale (c) ; spermathèque en vue ventrale et semi-latérale (d). L. thomasi : extrémité de l'abdomen du mâle en vue dorsale (e) et ventrale (f) ; extrémité de l'abdomen de la femelle en vue ventrale (g); spermathèque en vue ventrale et semi-latérale (h). L. occitana : extrémité de l'abdomen du mâle en vue dorsale (i) et ventrale (j); extrémité de l'abdomen de la femelle en vue ventrale (k) ; spermathèque en vue ventrale et semi-latérale (1). L marrocana : extrémité de l'abdomen du mâle en vue dorsale (m) et ventrale (n) ; extrémité de l'abdomen de la femelle en vue ventrale (o) ; spermathèque en vue ventrale et semi-latérale (p). 
4' Anterior part of the subgenital plate with a median narrowing. Antennae without a whorl of long hairs around the apex of each segment (Fig. $110, p$ )

maroccana

5 (3') Lobes very short and wide, adjacent, directed obliquely to outside and separated by a small triangular incision. They are sometimes hardly visible in ventral view (Fig. $11 \mathrm{~g}, \mathrm{k}$ )

5' Lobes differently shaped and better defined

6 (5) Subgenital plate with a small median triangular bulge. Lobes bent down to ventral side, and carrying a strong pale seta (Fig. $11 \mathrm{~g}, \mathrm{~h}$ )

6' Subgenital plate without any median bulge but with a strong anterior protrusion. Lobes hardly visible, covered with thin hairs (Fig. $11 \mathrm{k}, 1$

7 (5') Apex of the lobes truncated horizontally or obliquely; their inner angles are adjacent or separated by a narrow cleft. Armature of the spermatheca with the antero-posterior teeth slender, stick-shaped, connected by a slim sclerotized arc (Figs 12-13) (inermis gr.)

7' Apex of the lobes different in shape. Lobes separated by a more or less wide hollow. Armature of the spermatheca different in shape

8 (7') Lobes composing two adjacent semi-circular festoons on the subgenital plate hind margin (Fig. 6 k, 9 o)

8' Lobes different in shape

9 Lobes less pigmented than the rest of the subgenital plate, and widened at their apices (Fig. $6 \mathrm{k}$ )

$9^{1}$ Lobes more pigmented than the rest of the subgenital plate, and constricted at their apices (Fig. 9 o)

10 (8') Lobes almost adjacent

10' Lobes more widely separated

11 (10) A small lobule between the two lobes (Fig. $6 \mathrm{c}, \mathrm{g}$ )

11' No lobule between the two lobes (Fig. $10 \mathrm{c}, \mathrm{g}$ )

12 (11) Posterior edge of the subgenital plate regularly curved. Lobes very large and strong, and
6

7

vaillanti

occitana

hexacanthoides albida separated by a very small hollow (Fig. $6 \mathrm{c}$ )

12' Posterior edge of the subgenital plate sinuous. Lobes not so large and strong, and separated by a wider hollow (Fig. 6 g)

13 (11') Micropterous species with all tergites fully sclerotized. Posterior edge of the lobes slightly concave (Fig. $10 \mathrm{~g}$ )

13' Macropterous species with tergites 2 to 7 membranous. Posterior edge of the lobes rectilinear or convex (Fig. $10 \mathrm{c}$ )

14 (10') Apterous species with all tergites fully sclerotized. Inner angle of the lobes obtuse; deep and narrow hollow between the lobes (Fig. $10 \mathrm{k}$ )

14' Normally winged species with tergites 2 to 7 membranous

15 (14') Hollow between the lobes clearly wider than the width of one lobe (Fig. $7 \mathrm{n}, 8 \mathrm{c}, 8 \mathrm{k}, 9 \mathrm{k}$ )

despaxi

ariega

joani

prima

15' Hollow between the lobes about as wide as the width of one lobe, or less

clerguae

16 (15) Inner angle of the lobes acute (Fig. $7 \mathrm{n}, 8 \mathrm{k}$ )

16' Inner angle of the lobes rounded (Fig. $8 \mathrm{c}, 9 \mathrm{k}$ )

17 (16) Lightly pigmented area between the lobes very developed. Lateral edges of the subgenital plate slightly sinuous (Fig. 7 n)

17' Lightly pigmented area between the lobes poorly developed. Lateral edges of the subgenital plate slightly convex, but not sinuous (Fig. $8 \mathrm{k}$ )

18 (16') Lightly pigmented area between the lobes triangular. Lateral edges of the subgenital plate sinuous (Fig. $8 \mathrm{c}$ )

major

18' Lightly pigmented area between the lobes not triangular. Lateral edges of the subgenital plate slightly convex, but not sinuous (Fig. 9 k)

castillana

pseudocylindrica

19 (15') Hollow between the lobes about as wide as the width of one lobe

mortoni

19' Hollow between the lobes clearly less wide than the width of one lobe. Lightly pigmented area between the lobes rounded. Lateral edges of the subgenital plate sinuous (Fig. 7 i) 
20 (19) Lobes globular, clearly inclining towards each other. Lobes and subgenital plate sides strongly pigmented. Large hollow between the lobes (Fig. $11 \mathrm{c}$ )

20' Lobes subrectangular or slightly rounded at the tip

21 (20') A median lobule arising at the base of the lobes (Fig. $7 \mathrm{~d}$ )

21' No median lobule arising at the base of the lobes

22 (21') Lateral edges of the subgenital plate clearly convex (Fig. 9 c, 9 g)

22' Lateral edges of the subgenital plate subrectilinear and slightly sinuous (Fig. 7 r, 8 g)

23 (22) Lightly pigmented area between the lobes very large (Fig. $9 \mathrm{c}$ )

23' Lightly pigmented area between the lobes much smaller (Fig. $9 \mathrm{~g}$ )

24 (22') Lobes well developed, with rectilinear posterior edge. Lightly pigmented area between the lobes long and wide (Fig. 8 g)

24' Lobes much shorter, with rounded posterior edge (Fig. 7 r)

25 (7) Subgenital plate with a strongly prominent median bulge, close to the 8th sternum anterior margin (Fig. 13)

25' Subgenital plate just slightly inflated medially (Fig. 14)

26 (25) Hind margin of the lobes rectilinear and perpendicular to the body axis. Lobes separated by a thin and deep cleft. Median bulge subconical, nose-shaped in lateral view (Fig. 13 c, d)

26' Hind margin of the lobes clearly oblique or sinuous. Lobes not separated by a thin and deep cleft. Median bulge globular (Fig. 13 h-i, 13 m-n)

27 (26) Hind margin of the lobes oblique (Fig. $13 \mathrm{~h}$ )

$27^{\prime}$ Hind margin of the lobes sinuous. Inner angle of the lobes forming a small lobule (Fig. $13 \mathrm{~m}$ )

28 (25') Hind margin of the lobes slightly rounded, without any inner lobule. Subgenital plate less pigmented than the lobes, and flat in lateral view (Fig. $12 \mathrm{~g}$ )

28' Hind margin of the lobes sinuous with a well defined inner lobule. Subgenital plate as pigmented as the lobes, and provided with a median swelling, slightly prominent in lateral view (Fig. $12 \mathrm{c}$ )

\section{Key of the genus Pachyleuctra}

\subsection{Males}

hippopus

21

aurita

24

digitata

fusca

leptogaster

alticola

rauscheri

\section{7}

kempnyi

garumna

alosi

inermis
1 10th tergum provided with a long posterior expansion; its hind margin is sinuous with a tiny sclerotized lobule in the middle; the median membranous area is nearly circular, with two dark patches anteriorly. Specilla regularly curved inwards in lateral view; they end into a blunt apex (Fig $14 \mathrm{~d}, \mathrm{~g}, \mathrm{e}$ )

1' 10th tergum provided with a short posterior expansion; its hind margin is clearly concave; the median membranous area is bean-shaped, without any dark patches. Specilla slightly curved outwards in lateral view ; they end into a small inner hook (Fig $14 \mathrm{a}, \mathrm{b}$ )

bertrandi

2 (1) Paired processes on tergite 5, 7, 8,9 sharp and smooth (Fig. 14 d)

2. Paired processes on tergite 5, 7, 8, 9 blunt and rough (Fig. 14 g)

benllochi

ribauti

\subsection{Females}

1 Lobes of the subgenital plate widely separated (Fig. $14 \mathrm{f}, \mathrm{h}$ ). (The position of the lobes is rather variable during the mating period, and therefore, the report of $P$. ribauti in a new locality needs to be confirmed by the capture of males)

1 Lobes of the subgenital plate close together, and separated by a thin and deep cleft (Fig. 14 c)

benllochi ribauti

bertrandi

\section{Species list}

The available material of Pyrenean Leuctridae used in this study belongs to $G$. Vinçon personal collection. Other specimens are part of Berthélemy and Despax Plecoptera collections, which are stored in the Zoological Laboratory of the Toulouse University.

Drawings were made by $\mathrm{C}$. Ravizza from specimens stored in $80 \%$ alcohol, using a camera lucida mounted on a Wild M8 stereomicroscope.

In the species list, we give for each species, the original description reference, synonyms and works dealing with its taxonomy, followed by data on type locality, etymology, affinities, ecology and geographical distribution. 

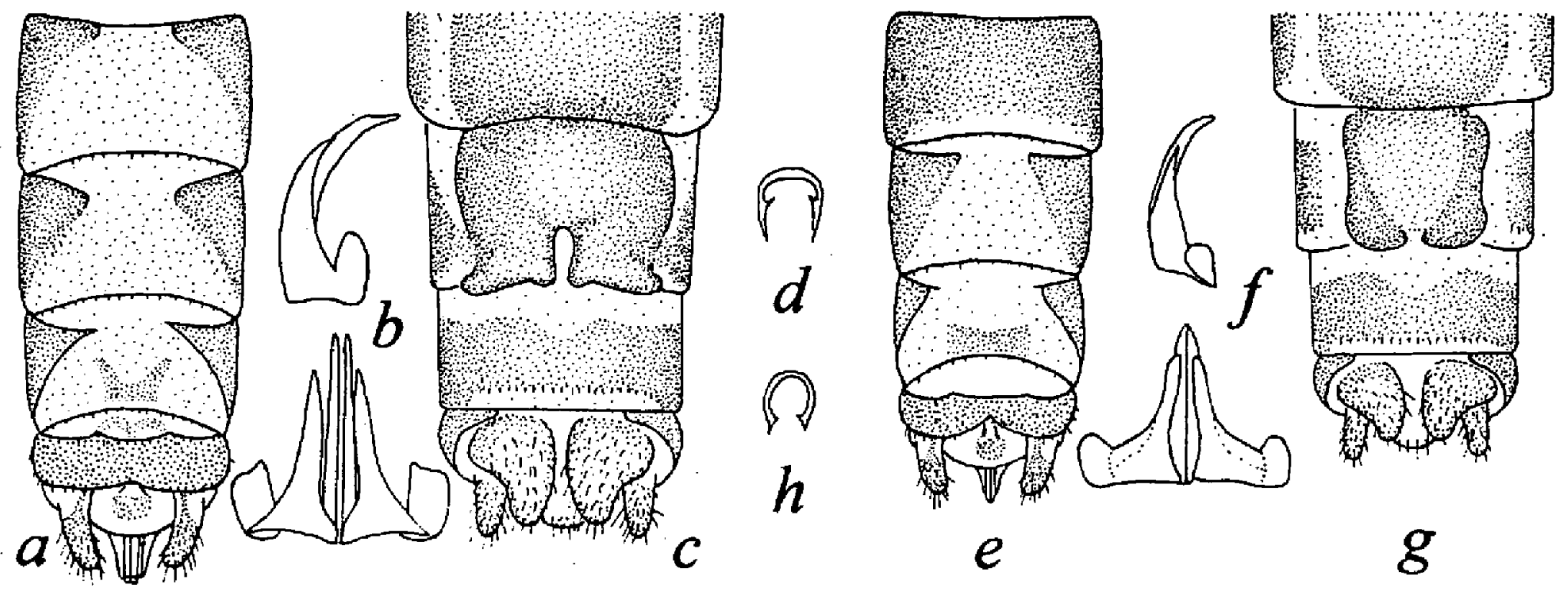

Fig. 12. Leuctra inermis : tip of the male abdomen in dorsal view (a) ; styli and specilla in lateral and ventral view (b) ; tip of the female abdomen in ventral view (c); spermatheca in ventral view (d). L. alosi : tip of the male abdomen in dorsal view (e); styli and specilla in lateral and ventral view (f) ; tip of the female abdomen in ventral view (g); spermatheca in ventral view (h).

Fig. 12. Leuctra inermis : extrémité de l'abdomen du mâle en vue dorsale (a) ; styles et specilla en vue latérale et ventrale (b) : extrémité de l'abdomen de la femelle en vue ventrale (c); spermathèque en vue ventrale (d). L alosi : extrémité de l'abdomen du mâle en vue dorsale (e); styles et specilla en vue latérale et ventrale (f) ; extrémité de l'abdomen de la femelle en vue ventrale (g) ; spermatheque en vue ventrale $(\mathrm{h})$.

\subsection{Genus Leuctra}

\subsection{1. «geniculata» group}

Leuctra geniculata (Stephens), 1836 (Fig. 3 a-e)

Nemoura geniculata Stephens $1836: 145$ fig. 4.

Leuctra geniculata Steph., Mosely $1932: 7$ figs. 1-2, tab. IV/7; Despax 1951 : 118 figs. 49-50; nlies $1955: 64$ fig. 56; Aubert 1959, 63 figs. 155-156.

Euleuctra geniculata Steph., Illies 1966 : 77.

Leuctra geniculata Steph., Kis 1974 : 85, 86 fig. 35a-d.

Type locality : Great Britain, Scotland (Illies, 1966).

Etymology : From Latin geniculatus = geniculate; this word probably derives from the sclerotized lobes projecting from the margin of the basal articles of the antennae of the nymphs.

Affinities : «geniculata» group. Its morphological characters clearly differentiate this species from all others in the Pyrenees.

Ecology : Riverine species living at low altitude. This species is endangered in Europe. The adults emerge from September to December.

Distribution : European species, also in Corsica and Sardinia, as well as in the Maghreb (distribution map in Zwick 1981). We have found this species in several places along the Pyrenean chain and in the lower Garonne Valley at Capens, $200 \mathrm{~m}$ a.s.l.

\subsection{2. «boreoni» group \\ Leuctra espanoli Aubert, 1956 (Fig. 4 a-h)}

Leuctra espanoli Aubert, 1956 : 232-235 fig. 44-51.
Type locality : Spain, Cantabrian Mountains, La Portilla, Rio Nevandi

Etymology : Dedicated to the Spanish entomologist F. Espafiol.

Affinities : «boreoni» group. L. espanoli is the second species belonging to this group.

Ecology : Rheophilic and crenophilic species living in high altitude brooks and springs $(900-1600 \mathrm{~m})$. Flight period from September to December.

Distribution : Endemic to the Cantabrian Cordillera but extending to the westem extremity of the Pyrenees where it seems rare. Two adults have been recorded for the first time on the northern slope of the Pyrenees : Spain, Pamplona, Río Luzane-Valcarlos tributary of the Nive River, on the northern slope of the Puerto de Ibañeta, $1000 \mathrm{~m}, 1<\mathrm{m}>, 20 . \mathrm{XII} .92$; France, Pyrénées-Atlantiques, spring under the Arthaburu Pic, tributary of the Nive de Beherobie, $900 \mathrm{~m}, 1<\mathrm{f}>$, 10.XI.87. It is new for the French Fauna.

\subsection{3. «berthelemyi» group}

Leuctra berthelemyi Zwick \& Vinçon, 1993 (Fig. 5 a-f)

Leuctra berthelemyi Zwick \& Vinçon, 1993 :

Type locality : France, Atlantic Pyrenees, Nive de Béhérobie Valley, $900 \mathrm{~m}$.

Etymology : Dedicated by the authors to the French entomologist Claude Berthélemy.

Affinities : «berthelemyi» group. Similar to L. braueri, but both its morphological characters, and the spermatheca shape show that this species cannot belong to the abraueri» group. 

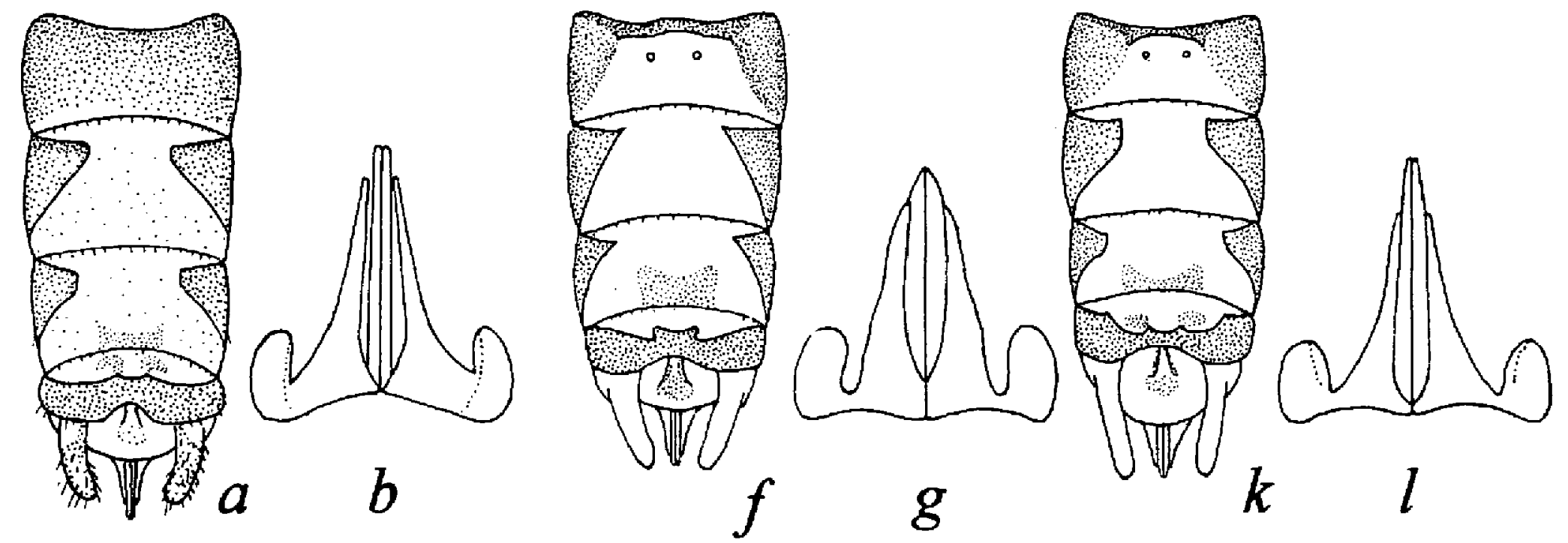

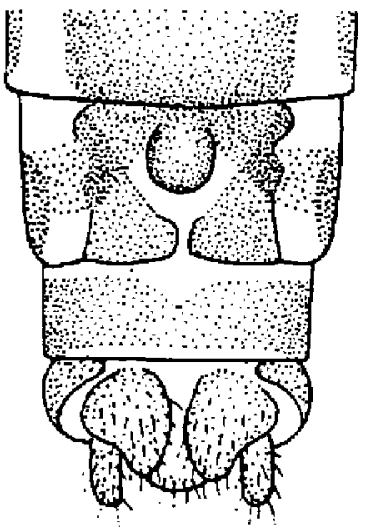

c
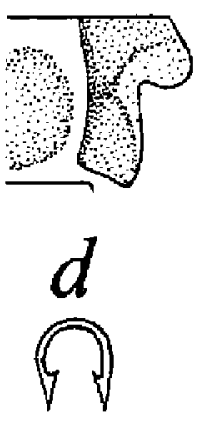

$e$
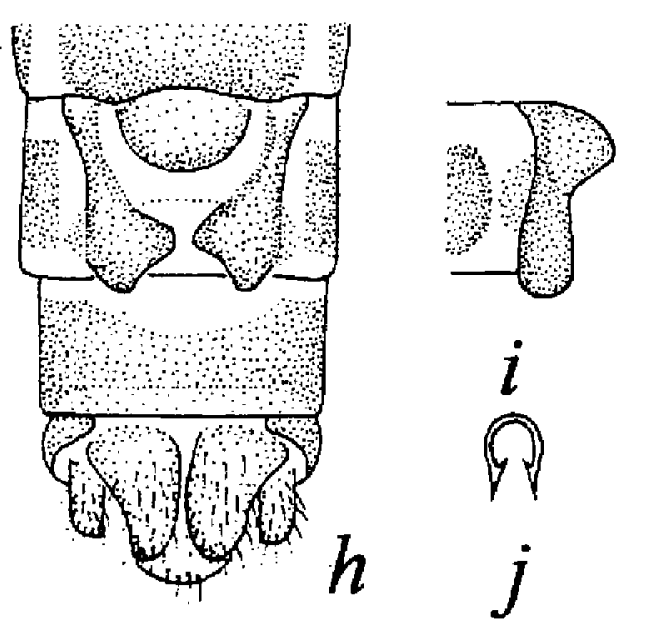

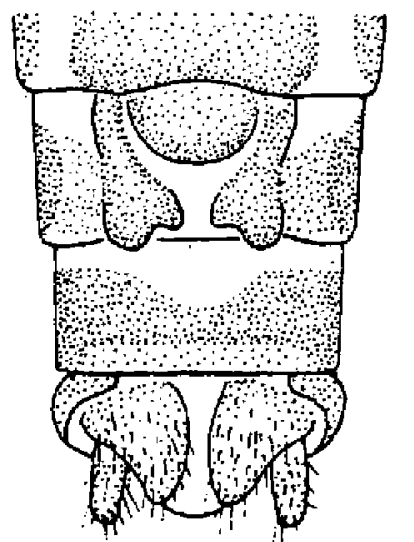

$m$

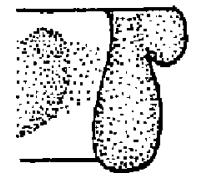

$n$

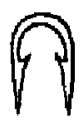

$O$

Fig. 13. Leuctra rauscheri : tip of the male abdomen in dorsal view (a) ; styli and specilla in ventral view (b) ; tip of the female abdomen in ventral view (c) ; female subgenital plate in lateral view (d) ; spermatheca in ventral view (e). L. kempnyi : tip of the male abdomen in dorsal view (f) ; styli and specilla in ventral view (g); tip of the female abdomen in ventral view (h) ; female subgenital plate in lateral view (i) ; spermatheca in ventral view (j). L garumna : tip of the male abdomen in dorsal view (k) ; styli and specilla in ventral view (1) ; tip of the female abdomen in ventral view (m); female subgenital plate in lateral view (n) ; spermatheca in ventral view (o).

Fig. 13. Leuctra rauscheri : extrémité de l'abdomen du mâle en vue dorsale (a); styles et specilla en vue ventrale (b) ; extrémité de l'abdomen de la femelle en vue ventrale (c) ; plaque sous-génitale en vue latérale (d); spermathèque en vue ventrale (e). L. kemp$n y i$ : extrémité de l'abdomen du mâle en vue dorsale (f); styles et specilla en vue ventrale (g); extrémité de l'abdomen de la femelle en vue ventrale (h) ; plaque sous-génitale en vue latérale (i) ; spermathèque en vue ventrale (j). L. garumna : extrémité de l'abdomen du mâle en vue dorsale (k) ; styles et specilla en vue ventrale (l); extrémité de l'abdomen de la femelle en vue ventrale (m) ; plaque sous-génitale en vue latérale (n); spermathèque en vue ventrale (o).

Ecology : Cold stenothermous, rheophilic and crenophilic species, restricted to the headwater of brooks near to their source $(600-1300 \mathrm{~m})$. Adults are on the wing mainly in autumn and winter (VIII-XII), exceptionally in spring.

Distribution : Western Pyrenees. Endemic to a restricted area in the Pyrénées-Atlantiques (France) and Pamplona province (Spain).

\subsection{4. «fusca» group}

Leuctra despaxi Mosely, 1930 (Fig. 6 a-d)

Leuctra despaxi Mosely, 1930 : 249; 1932 : 10, fig. 5-8. Despax

$1951: 141-143$, fig. 61 a-.b.

Type locality: France, Pyrénées-Orientales.

Etymology : Dedicated to the French entomologist Raymond Despax.

Affinities : «fusca» group, «aurita» sub-group.
Ecology : Crenophilic, cold stenothermous species, living in mountain brooks and springs (400-2000 m). It shows preferences for the calcareous massifs where the adults can be found in great quantities close to the stream losses and even in the caves (for example : loss of the Rossignol torrent and «Gueil di Her» cave, in the Arbas massif, Haute-Garonne) . The adults emerge in spring and early summer (IV-VII).

Distribution : French Massif-Central, Pyrenees and Northwestern Spain.

Leuctra ariega Pardo \& Vinçon, 1995 (Fig. 6 e-h) Leuctra ariega Pardo \& Vinçon, 1995.

Type locality : France, Pyrenees, Ariège, Vicdessos Valley, Soulcem brook, «Orris de la Crouts», $1850 \mathrm{~m}$.

Etymology: Named after the Ariège River, tributary of the Garonne River. 

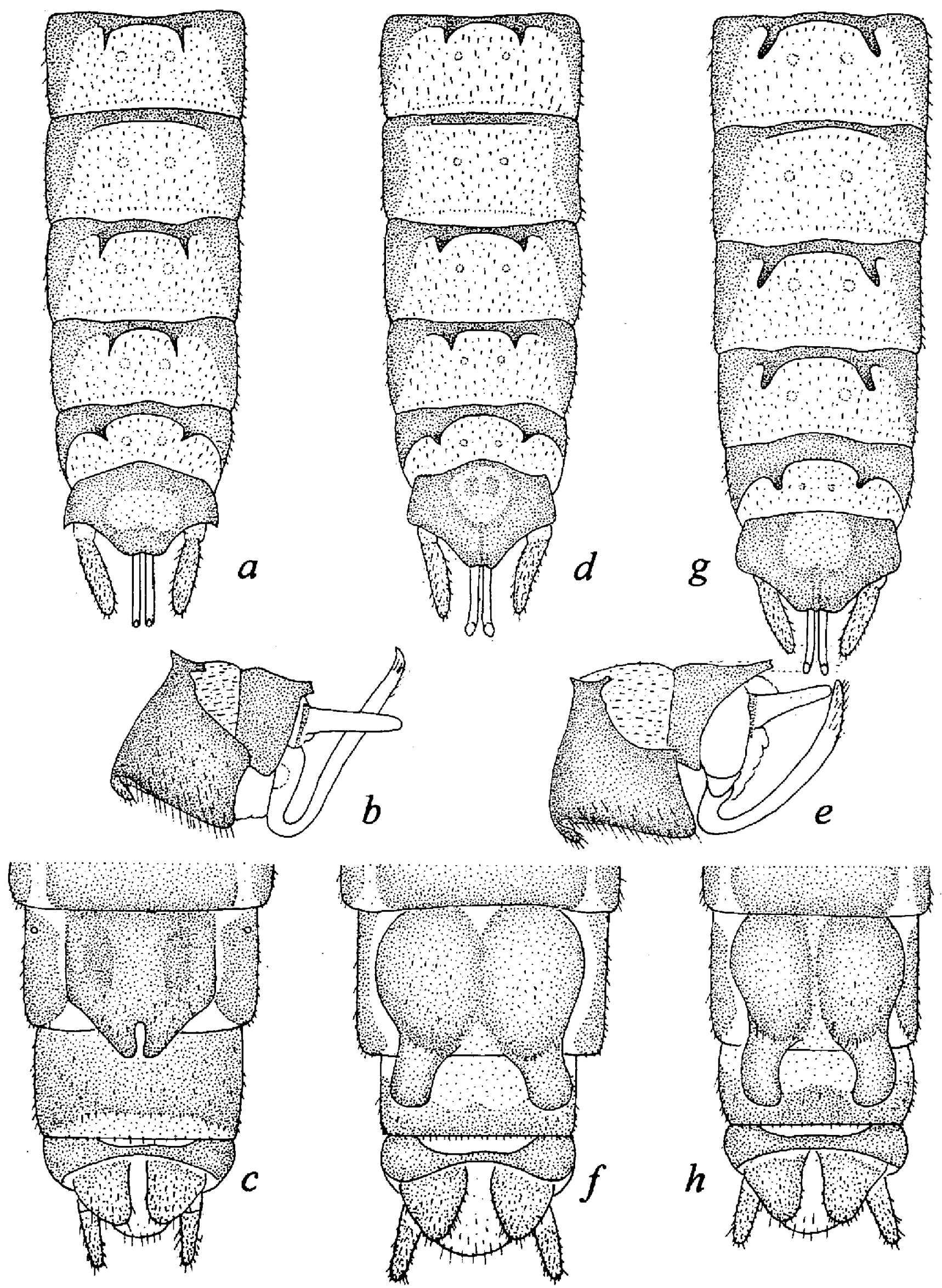

Fig. 14. Pachyleuctra bertrandi : tip of the male abdomen in dorsal view (a); specillum in lateral view (b) ; tip of the female abdomen in ventral view (c). $P$. benllochi : tip of the male abdomen in dorsal view (d); tip of the female abdomen in ventral view (f). $P$. ribauti : tip of the male abdomen in dorsal view $(\mathrm{g})$; female subgenital plate in ventral view (h). $P$. benllochi and $P$. ribauti : specillum in lateral view (e).

Fig. 14. Pachyleuctra bertrandi : extrémité de l'abdomen du mâle en vue dorşale (a); specillum en vue latérale (b); extrémité de l'abdomen de la femelle en vue ventrale (c). P. benllochi : extrémité de l'abdomen du mâle en vue dorsale (d); extrémité de l'abdomen de la femelle en vue ventrale (f). $P$. ribauti : extrémité de l'abdomen du mâle en vue dorsale (g) ; extrémité de l'abdomen de la femelle en vue ventrale (h). $P$. benllochi and $P$, ribauti : specillum en vue latérale (e). 
Affinities : «fusca» group, «aurita» sub-group. Close to $L$. despaxi but easily recognisable in both sexes.

Ecology : Strongly orophilic, cold stenothermous species inhabiting springs and brooks between 1850 and $2450 \mathrm{~m}$. The adults fly in spring just after the snow melts (V)

Distribution : Eastern Pyrenees. This species is localised in a very restricted part of the Pyrenean chain covering the Andorra and the Ariège department. It was previously only reported from the type locality (Pardo \& Vinçon, 1995), but we have found it in three other places in the same region, on both the northern and southern slopes : Ariège, spring tributary of Vicdessos River, «Pla Subra», east side of the Montcalm Pic, $1950 \mathrm{~m}, 2<\mathrm{m}\rangle, 2<\mathrm{f}\rangle$, 25. V.95. Andorra, Arinsal, spring of the Coma Pedrosa, $2450 \mathrm{~m}, 3<\mathrm{m}>, 1<\mathrm{f}>$, 25.V.95, Coma Pedrosa torrent, $2100 \mathrm{~m}, 3<\mathrm{f}>, 25$. V.95. It is new for the Iberian Peninsula.

Leuctra hexacanthoides Zwick \& Vinçon, 1993 (Fig. 6 i-1) Leuctra hexacanthoides Zwick \& Vinçon, 1993.

Type locality : Spain, Pyrenees, Pamplona, Nive d'Arnéguy Valley, Río Luzane Valcarlos, $1000 \mathrm{~m}$.

Etymology : Similar to L. hexacantha Despax, 1940 (referring to the 6 tergal processes on the male abdomen)

Affinities : «fusca» group, «aurita» sub-group. L. hexacanthoides shares more affinities with $L$. despaxi and $L$. arie$g a$ than with the alpine species $L$. hexacantha that belongs to another sub-group ( fusca» sub-group).

Ecology : Rheophilic species that inhabits different types of streams between 500 and $1500 \mathrm{~m}$. Its emergence time extends from August to December.

Distribution: Western Pyrenees. Distributed in the French Pyrénées-Atlantiques and the Spanish Pamplona province.

\section{Leuctra aurita Navás, 1919 (Fig. 7 a-e}

Leuctra aurita Navás, 1919 : 192 fig. 2; Mosely 1932 : 37-38 ; Despax 1951 : 130 fig. 55c-d ; Illies $1955: 67$ fig. 59c-d ; Kis 1974 : 93, 95 fig. 43a-e.

Leuctra cincta $=$ aurita Morton, $1929: 131$. Mosely $1932: 31$ figs. $48-49 \mathrm{pl} . \Pi / 12$.

Type locality : Spain, Gerona, Viladrau.

Etymology : From Latin auritus = with great ears, because of the shape of the 6th tergum processes reminding two ears.

Affinities : «fusca» group, «aurita» sub-group. Close to $L$. lamellosa.

Ecology : Inhabits different watercourses between 300 and $2300 \mathrm{~m}$. Its emergence time extends from August to December.

Distribution : Central-European. This species is common throughout the Pyrenean chain.

\section{Leuctra lamellosa Despax, 1929 (Fig. 7 f-j)}

Leuctra lamellosa Despax,1929 : 175 fig. 7-9.; Mosely 1932 : 29 pl. I/5 ; Despax,1951 : 128 fig. 55a-b.

Type locality : France, Haute-Garonne, Saint-Béat, forest of «Artigue de Prat».
Etymology : From Latin lamella = thin plate, and also from French lamelleuse $=$ provided with thin plates. The name stresses the shape of the tergal processes of the male.

Affinities : «fusca» group, «aurita» sub-group. Closely related to $L$ castillana from which it differs mainly by the shape of the paraprocts styles, and $L$. aurita from which it can be distinguished by the wider 6th tergum processes and by the smaller ventral vesicle, in the male. The female is much easier to identify.

Ecology : Orophilic and theophilic species living chiefly in small mountain brooks between 300 and $2200 \mathrm{~m}$. Flight period VIII-XII.

Distribution : Pyreneo-Cantabrian species. Widespread in the whole Pyrenean chain.

Leuctra castillana Aubert, 1956 (Fig. 7 k-o)

Leuctra castillana Aubert 1956 : 237-239 figs. 52-53, 58, 61, 67-68.

Type locality : Spain, Cantabrian Mountains, Puerto de Pajares

Etymology : From the Castilla, Iberian region which gave the name to the kingdom of Castilla.

Affinities : «fusca» group, «aurita» sub-group. Closely related to $L$ aurita and L. lamellosa, from which the male can be separated by the shape of the paraprocts styles. The females can be confused with those of $L$. pseudocylindrica or L. major.

Ecology: In the Pyrenees, it lives mainly at low altitude, in brooks and streams (300-1000 m), exceptionally in higher watercourses $(1000-2000 \mathrm{~m})$. The adults emerge from summer to winter (VI-II), but mainly in autumn.

Distribution : Central and northern Spain, Pyrenees and French Massif-Central. Common in the whole Pyrenean chain.

Leuctra alticola Despax, 1929 (Fig. 7 p-s)

Leuctra albida subsp. alticola Despax, 1929 : 169.

Leuctra alticola Mosely, 1932 : 36, pl L6 ; Despax 1951 : 134, fig. $57 \mathrm{a}-\mathrm{b}$.

Type locality : France, Hautes-Pyrénées, Néouvielle massif, Estaragne torrent, at $2200 \mathrm{~m}$.

Etymology : From French alticole : chiefly at high altitudes.

Affinities : «fusca» group, «aurita» sub-group. By the processes of the 6th and 7th terga $L$. alticola could be confused with $L$. albida, but in fact they are quite different in both sexes and not assigned to the same subgroup. In our opinion, $L$. alticola shares more affinities with $L$ aurita, $L$. lamellosa and L. castillana (Fig. 9).

Ecology : Strongly orophilic and cold stenothermous species, scattered in high altitude springs and brooks (1200$2550 \mathrm{~m}$ ), mainly above $2000 \mathrm{~m}$. Emergence occurs from July to September.

Distribution : Pyrenean. Endemic to the highest part of the Pyrenean chain, on both French and Spanish slopes (Tab. 1) 
Leuctra major Brinck, 1949 (Fig. 8 a-d)

Perla cylindrica De Geer 1778 : 599-600 pl. XLIV/17-19.

Leuctra cylindrica = major Kühtreiber, $1934: 64$ fig. $45 ;$ Mosely 1932 : 8 fig. 3 pl. IV/18 ; Despax 1951 : 130-132 fig. 56a-b.

Leuctra major, Brinck 1949 : 12 fig. (nom. nov. for Leuctra cylindrica Pictet and other authors nec De Geer). Illies 1955 : 69 fig. 62a-b ; Aubert 1959:59, 60, 66 figs. 162, 172 ; Aubert $1959: 59$. 60, 66 figs. 162,172 ; Kis 1974 : 93-94 fig. 42a-e

Type locality : Switzerland, Geneva (Illies, 1966)

Etymology : From Latin major = large, great, size on average larger than that of the other Leuctra species.

Affinities : «fusca» group, «aurita» sub-group. Close to $L$. pseudocylindrica and $L$. castillana in both sexes. The males are easier to separate than the females.

Ecology : In the Pyrenees, L. major mainly inhabits submontane watercourses, $300-1400 \mathrm{~m}$. The elongate and rather hairless nymphs live in the hyporheic zone (Berthélemy, 1968). Emergence occurs from August to November.

Distribution : Centra]-S-European. Very rare on both slopes of the Pyrenean chain (Tab. 1). In northern Spain, it is only known with certainty from one locality (Sierra de Albarracin, Aubert 1963).

\section{Leuctra leptogaster Aubert, 1949 (Fig. 8 e-h)}

Leuctra leptogaster, Aubert, 1949 : 232-233 figs. 16-18; Illies 1955 : 69 fig. 62c-e ; Aubert 1959:59. 60, 66 figs. 161, 173.

Type locality : Switzerland, Lausanne, Bois du Belmont.

Etymology : From Greek leptogaster = abdomen thin and slender.

Affinities : «fusca» group, «aurita» sub-group. Related to L. major from which both sexes are easy to separate.

Ecology : In the Pyrenees, this species lives in different watercourses, from 300 to $1400 \mathrm{~m}$. Emergence occurs from September to November.

Distribution : Central-S-European. Widespread on both slopes of the Pyrenean chain, but always scarce. Its presence in the Cantabrian Cordillera (Puig et al. 1984) remains doubtful, since the identifications are based on larvae. It is probably absent from central and southern Spain.

\section{Leuctra pseudocylindrica Despax, 1929 (Fig. 8 i-l)}

Leuctra pseudocylindrica Despax, 1929 : 170, fig. 3-6 ; $1951: 132$, fig. $56 \mathrm{c}-\mathrm{d}$.

Type locality : France, Pyrenees, Haute-Garonne, SaintBéat, Mourtis forest.

Etymology : Similar to L. major, that in the past was for a long time known under the name of $L$. cylindrica.

Affinities : «fusca» group, «aurita» sub-group. Close to $L$. major, from which the male may be distinguished by the smaller processes on the 7 th tergum, and the female, by the shallower notch at the hind margin of the subgenital plate.

Ecology : Orophilic, cold stenothermous species, living mainly in springs and brooks between $800-1800 \mathrm{~m}$. It can also be found at lower altitudes $(400-800 \mathrm{~m})$, but only near springs. The adults emerge from July to December.
Distribution: Pyrenean species, slightly extensive in the eastern part of the Cantabrian Cordillera (País Basco). In the Pyrenees, it occurs in the western and central part of the chain up to the Spanish Val d'Aran where we have found it in the Río Negro, near Biella $(1<\mathrm{m}>, 1$.VIII.89) (Tab. 1)

Leuctra digitata Kempny, 1899 (Fig. 9 a-d)

Leuctra digitata Kempny, 1899 : 13 pl. I/4 a-c ; Mosely 1932 : 29-30 figs. 44-45 pl. I/9 ; Despax 1951 : 137 fig. 59 a-b ; Illies 1955 : 69 fig. 63; Kis, 1974 : 97 fig. 45a-e.

Type locality : Austria, low Austria, Gutenstein (Gutensteiner Alpen).

Etymology : From Latin digitatus = finger-shaped, after the shape of the tergal processes.

Affinities : «fusca» group, «fusca» sub-group. The peculiar morphological characters of this species in both sexes allow easy separation from all the other Pyrenean Leuctra species.

Ecology : In the Pyrenees, it inhabits submontane watercourses between $300-1000 \mathrm{~m}$. The adults emerge from August to December.

Distribution :Middle-N-European. In the Pyrenees, it is only known from the eastern and central part of the chain (Tab. 1). In the Iberian Peninsula its distribution is restricted to Cataluña; the mention of this species from the Spanish Cantabrian Cordillera (Puig \& al. 1984) is probably erroneous (Sánchez-Ortega \& Alba-Tercedor 1987).

Leuctra fusca (Linné), 1758 (Fig. 9 e-h)

Phryganea fusca Linné, 1758 : 549.

Leuctra cylindrica = fusca Klapalek (nec De Geer), $1896: 697-701$ pl. $1 \mathrm{~T} / 9-19$.

Leuctra klapaleki $=$ fusca Kempny, $1898: 217-219 \mathrm{pl}$. III/2.

Leuctra fusciventris = fusca Stephens, Mosely $1932: 32-33$, figs. 50-51, pl. II/7 ; Despax 1951 : 134-136, fjg. $58 \mathrm{c}$-d.

Leuctra fusca Illies $1955: 71$ fig. 65 ; Aubert $1959: 59,63,65$ figs. 163, 174 ; Kis, 1974 : 88-89 fig. 38a-e.

Type locality : Sweden, Fahlun (Tlies 1966)

Etymology : From Latin fuscus = black; because of the dark color of this species, a characteristic common in most Leuctra species.

Affinities : «fusca» group, «fusca» sub-group. The male may be easily distinguished from the other Leuctra belonging to the «fusca» group, by the shape of the 6th and 7th processes. The female subgenital plate is similar to that of the related species, $L$. digitata and $L$. mortoni.

Ecology: In the Pyrenean chain, L. fusca inhabits lowland rivers and streams up to $1400 \mathrm{~m}$. This species may tolerate a rather high level of pollution. It emerges from August to January.

Distribution :Euro Siberian. Widespread in the whole Pyrenean chain and in the Iberian Peninsula.

Leuctra mortoni Kempny, 1899 (Fig. 9 i-1)

Leuctra mortoni Kempny, 1899 : 271-272, P1. 6/3a-c ; Mosely 1932 : 28-28 fig. 41 pl. V/23; Kühtreiber 1934 : 74 fig. 54; Despax 1951 : 121-122 fig. 52 ; Illies 1955 : 65 fig. 57; Aubert 1959 : 59, 63, 65 figs. 165,176 ; Mendl $1968 \mathrm{c}: 70$; Kis $1974: 92-93$ fig. $41 \mathrm{a}-\mathrm{e}$. 
Type locality : Austria, Friesach (Mandnitzer Alpen).

Etymology : Dedicated to the British entomologist Kenneth J. Morton.

Affinities : «fusca» group, «fusca» sub-group. Male may be confused with $L$. moselyi from which it may be distinguished by the shape of the tergal processes. The female subgenital plate is similar to that of the related $L$. fusca and $L$. digitata.

Ecology : In the Pyrenees, it occurs in rather large submontane watercourses between 400 and $1420 \mathrm{~m}$. Emergence from August to November.

Distribution :Central-S-European. In the Pyrenees, it is only known from the central and western part of the chain (Tierno de Figueroa \& Sánchez-Ortega, 1995) (Tab. 1).

Leuctra albida Kempny, 1899 (Fig. 9 m-p)

Leuctra albida Mosely, 1932 : 35 fig. $54-55$ pl. V/27-27a ; Kühtreiber 1934 : 73-74 fig. 53 ; Despax 1951 : 133-134 fig. 57 ; Illies 1955 : 70 fig. 64 ; Aubert $1959: 59,62,66$ figs. 167, 178 ; Kis 1974 : $91-92$ fig. $40 \mathrm{a}-\mathrm{e}$.

Type locality : Austria, Gutenstein (Gutensteiner Alpen).

Etymology : From Latin albidus $=$ white, light, pale. The name recalls that the color of this species is generally less dark than the other Leuctra.

Affinities : «fusca» group, «fusca» sub-group. It can be confounded with $L$ mortoni or L alticola.

Ecology : In the Pyrenees, it lives in submontane brooks and streams $(300-1300 \mathrm{~m})$. It emerges from August to November.

Distribution : Central-European. In the Pyrenees, it is restricted to the northern slope of the chain and has never been found in the eastern part (Tab. 1).

\subsection{5. «hippopus» group}

Leuctra prima Kempny, 1899 (Fig. 10 a-d)

Leuctra prima, Kempny, 1899 : 9-10 Pl. I/1 ; Mosely $1932: 25 \mathrm{pl}$. I/4-4a ; Kühtreiber 1934 : 70 fig. 51 ; Despax $1951: 147$ fig. 65a-b ; Illies 1955 : 75 fig. 71a-b ; Aubert 1959 : 60, 62, 68-69 figs. 190, 199; Kis 1974 : 107-108 fig. 55a-e

Type locality : Austria, Kärnten, Radesbach.

Etymology : From Latin prima $=$ first, this species is one of the first Leuctra emerging in winter.

Affinities : «hippopus» group, «prima» sub-group ; closely related to the micropterous species $L$. joani.

Ecology : In the Pyrenees, it mainly inhabits submontane trickles and brooks at altitudes ranging from 300 to $1400 \mathrm{~m}$. Emergence begins in December and continues through May.

Distribution : Middle-European. We have collected L. pri$m a$ for the first time in the Iberian peninsula : Gerona, southem slope of «Col des Ares», Casasa torrent, tributary of Río Rilort, 1300 m, $9<\mathrm{m}>, 8<\mathrm{f}, 24 . X I I .92$.

Leuctra joani Vinçon \& Pardo, 1994 Fig. $10 \mathrm{e}-\mathrm{h}$ )

Leuctra joani Vinçon \& Pardo, 1994 : 205-28 figs. 1, 2b.
Type locality : France, Pyrénées-Atlantiques, Vert d'Arête Valley, Chousse brook, $1100 \mathrm{~m}$.

Etymology: Dedicated to Joan, son of Marinette and Gilles Vinçon.

Affinities : «hippopus» group, «prima» sub-group. Micropterous species, related to $L$ prima, from which the male differs by the tergal processes and the strongly reduced ventral vesicle, and the female, by the slender subgenital plate lobes.

Ecology : Rheophilic and crenophilic species, so far collected in a few springs and rivulets, between 1000 and 1200 $\mathrm{m}$. Emergence occurs in late autumn, winter and early spring (XI-IV).

Distribution : Endemic to the western Pyrenees. All collecting sites are in the French territory, but one of them is in the high Río Irati valley, that is in the Ebre drainage basin (Vinçon \& Pardo 1994). Since it has been collected on both slopes of the Pyrenean chain, it should be included in the current list of the Iberian Stoneflies (Sánchez-Ortega \& Tierno 1996).

Leuctra clerguae Vinçon \& Pardo, 1994 (Fig. $10 \mathrm{i}-1$ )

Leuctra clerguae Vinçon \& Pardo, 1994 : 205-212, fig. 3.

Type locality : France, Pyrénées-Atlantiques, Gave de Sainte-Engrâce Valley.

Etymology : Dedicated to the French entomologist Monique Clergue.

Affinities : «hippopus» group, «prima» sub-group. Species entirely wingless in both sexes. The $\langle m>$ is similar to that of $L$. ligurica Aubert, but its forked tergal process is clearly shorter, and the subgenital plate of the $\langle\mathrm{f}\rangle$ is very different.

Ecology : Rheophilic and crenophilic species, inhabiting small springs and trickles, at altitudes ranging from 900 to $1100 \mathrm{~m}$. Adults emerge in late Autumn, from October to December.

Distribution :Western Pyrenees. This species is only known from three localities, all belonging to the Adour hydrographic basin. One of them is settled in the Spanish territory, but on the northern slope of the Pyrenees : Pamplona province, southwards Puerto de Ibañeta, Río Luzane Valcarlos, $1000 \mathrm{~m}$ (Vinçon \& Pardo 1994). L. clerguae has never been collected on the southern slope of the Pyrenees, and therefore it should not be included in the current list of the Iberian Stoneflies (Sánchez-Ortega \& Tiemo 1996).

Leuctra hippopus Kempny, 1899 (Fig. 11 a-d)

Leuctra hippopus, Kempny, 1899 : $10 \mathrm{pl}$. I/2; Mosely 1932 : $20-21 \mathrm{pl}$. V1-2a ; Kühtreiber 1934 : 69 fig. 50 ; Despax 1951 : 142-143 fig. 62ab; Illies 1955: 71-72 fig. 67 ; Aubert 1959: 59, 63, 67 figs. 183,193 ; Kis 1974 : 98-10l fig. 48a-e ; Ravizza 1985 : 63-69, fig. If-l.

Type locality : Austria, Gutenstein (Gutensteiner Alpen).

Etymology : Derives from the Greek word hippopous = horse, because the tip of each of the 8th tergum processes is similar to a horse hoof (Mosely 1932). 
Affinities : «hippopus» group, «hippopus» sub-group. Easy to separate from all the other Pyrenean species, as its closest forms do not occur in the Pyrenees.

Ecology : In the Pyrenees, it inhabits various submontane watercourses between 250 and $1400 \mathrm{~m}$. Emergence from March to June.

Distribution : Eurosiberian. Widespread in the whole Pyrenean chain and in the northern part of the Iberian Peninsula.

Leuctra thomasi Zwick \& Vinçon, 1993 (Fig. 11 e-h)

Leuctra thomasi Zwick \& Vinçon, 1993.

Type locality : Andorra, Pyrenees, Coma Pedrosa, $2300 \mathrm{~m}$

Etymology : Dedicated to the French entomologist Alain Thomas, who collected the first specimens of this species.

Affinities : «hippopus» group, «occitana» sub-group. Related to $L$. occitana from which it is easy to separate.

Ecology : Orophilic, rheophilic, cold stenothermous species. It lives chiefly in high altitude brooks and torrents, between 1800 and $2700 \mathrm{~m}$, and it is very rare below. The adults emerge from July to October.

Distribution : Central Pyrenees. Endemic to a restricted area in the central part of the Pyrenees, from Andorra and Ariège to Aragon (Zwick \& Vinçon 1993, Tierno de Figueroa \& Sánchez-Ortega 1995).

\section{Leuctra occitana Despax, 1930 (Fig. 11 i-l)}

Leuctra occitana Despax, 1930a : 171-176 figs. 1-6; Mosely 1932 : 21-22 figs. 27-28 ; Despax 1951 : 120-121 fig. 51a-b.

Type locality : France, Saint-Martory, Larramette, Near Toulouse

Etymology : Derives from Occitanie, region in the south of France where the "langue d'oc" was the common language.

Affinities : «hippopus» group, «occitana» sub-group. $L$. occitana is related to $L$ thomasi (Pyrenees) and to some North African species : L. vaillanti Aubert, 1956, L. medjerdensis and L. khroumiriensis Vinçon \& Pardo, 1998.

Ecology : Rheophilic species. In the Pyrenees, it is only known from lowland brooks ( $150 \mathrm{~m}$ a. s. 1.) while in Spain it occurs in high altitudes watercourses (1000- $1500 \mathrm{~m}$ ) (Vinçon \& Pardo 1998). The flight period is in winter (XI-III).

Distribution :Western Mediterranean species, extending from Andalusia to the South of France (Var and Haute-Garonne) (Vinçon \& Pardo 1998). In the Pyrenees, it is only reported from the region of Toulouse (Despax 1930), and has never been collected on the southern slope of the chain.

Leuctra maroccana Aubert, 1956 (Fig. $11 \mathrm{~m}-\mathrm{p}$ )

Leuctra maroccana Aubert, 1956; Berthélemy 1968 : 190-191 fig. $22-25$

Type locality : Morocco, Moroccan Great Atlas, M'Goun Massif, spring of the asif M'Goun.

Etymology: The typical species comes from Morocco.

Affinities : «hippopus» group, «occitana» sub-group. This species is clearly separated from all the other Pyrenean Leuctridae.
Ecology : Orophilic and crenophilic species. In the Pyrenees, it is confined to the foothill watercourses (100$1000 \mathrm{~m}$ ), while in the rest of the Iberian Peninsula it lives chiefly at higher altitudes (500-1800 m), near the springs. Emergence occurs in winter and early spring (XII-T).

Distribution :Western Mediterranean species. It extends from the Moroccan High Atlas to the French Atlantic Pyrenees. In the Pyrenees, it is restricted to the western extremity of the chain (Pyrénées-Atlantiques and Navarra).

\subsection{6. «inermis» group}

Leuctra inermis Kempny, 1899 (Fig. 12 a-d)

Leuctra inermis, Kempny, $1899: 270$ pl. VI/a-c ; Mosely $1932: 13-$ 14 pl. 16-16a; Kühtreiber 1934 : 77-79 fig. 56 ; Despax $1951: 124$ fig. 53a-b ; Illies 1955 : 66 fig. 58a-d ; Aubert $1957: 290,291-292$ figs. 9-14; Aubert $1959 ; 58,62,70$ figs. 203, 208, 214 ; Kis 1974 : 109, 111 fig. 58a-e.

Type locality : Austria, Alps, Gutenstein (Gutensteiner Alpen).

Etymology : From Latin inermis = unamed. The male of this species lacks any tergal process.

Affinities : «inermis» group. Close to L. handlirschi.

Ecology : In the Pyrenees, this eurytopic species inhabits all kinds of montane watercourses between 400 and $2400 \mathrm{~m}$. The flight period extends from April to August.

Distribution : European. Widespread throughout the Pyrenean chain and in the whole Iberian Peninsula.

Leuctra alosi Navás, 1919 (Fig. 12 e-h)

Leuctra alosi Navás 1919.

Type locality : Spain, Lérida

Etymology : unknown.

Affinities : «inermis» group. Close to L. handlirschi (Alps) and L. flavomaculata (French Massif-Central).

Ecology : Rheophilic and orophilic species. In the Pyrenees, $L$ alosi lives mostly in submontane watercourses (100 $-1700 \mathrm{~m}$ ), but it also colonises higher altitude brooks (1700$2300 \mathrm{~m}$ ), mainly on the southern slopes subject to favourable thermal conditions. The adults emerge from May to September.

Distribution :North-western part of the Iberian Peninsula and in the Pyrenees. Widespread in the whole Pyrenean chain.

Leuctra rauscheri Aubert, 1957 (Fig. 13 a-e)

Leuctra teriolensis, Mosely, 1932 : Leuctra inermis, Kühtreiber ; 1934 : pro parte Leuctra teriolensis Despax 1951 : 125 fig. $53 \mathrm{e}-\mathrm{f}$.

Leuctra rauscheri, Aubert, 1957 : 290, 295-298 figs. 24-30 ; Aubert $1959: 58,62,70$ figs. 207,212 ; Kis $1974: 113-114$ fig. 60a-f.

Type locality : Switzerland, Alpes du Valais, Entremont valley, Proz.

Etymology : Dedicated to the Czech entomologist Jaroslav Rauser.

Affinities : «inermis» group. Close to $L$. kempnyi and $L$. garumna, with which it may be confused in both sexes. 
Ecology : Rheophilic, strongly orophilic, cold stenothermous species. In the Pyrenees, $L$. rauscheri lives mainly in high altitude brooks and torrents (1300-2500 m). Exceptionally, it can be found at lower altitudes near cold springs (850-1300 m). The flight period extends from April to August, but mostly in summer.

Distribution :Central-South-European. In the Pyrenees, it is limited to the highest part of the chain ; it does not extend into the Iberian Peninsula.

Leuctra kempnyi Mosely, 1932 (Fig. 13 f-j)

Leuctra kempnyi Mosely, 1932 : 14, pl. III/1 ; Despax 1951 : 125126, fig. 53 c-d; Berthélemy 1968 : 192 fig. 27, 29, 31

Type locality : France, Pyrénées-Atlantiques, Ossau valley, Eaux-Bonnes.

Etymology : Dedicated by Mosely to the Austrian entomologist P. Kempny.

Affinities: "inermis" group. It is closely related with L. garumna.

Ecology : Crenophilic species. Restricted to montane springs and brooklets $(400-1600 \mathrm{~m})$. Flight period extends from spring to summer (III-VIII), but mainly at the end of spring (V-VI).

Distribution : Pyreneo-Cantabrian species. Endemic to a restricted area covering the western Pyrenees and the eastern Cantabrian Cordillera where it extends up to Puerto de la Sia (Cantabria)

Leuctra garumna Vinçon and Ravizza, 1996 (Fig. 13 k-o)

Leuctra garumna Vinçon and Ravizza, 1996 : figs 11-17.; Berthélemy $1968: 192$ fig. $28,30,32$

Type locality : France, Haute-Garonne, Ger valley, Rossignol brook.

Etymology : From Garumna Latin name of the Garonne river.

Affinities : "inermis" group. Closely related to L. kempnyi with which it has been confused for a long time in the Pyrenees. The male can be separated by its membranous 7 th tergum with narrow anterior margin, and by the rounded shape of the 10th tergum hollow; the female by the sinuous hind margin of the lobes with well defined inner lobule. L. garumna is also close to the Alpine species L. ameliae.

Ecology : Crenophilic species, living mainly in high altitude springs and brooklets $(1000-2000 \mathrm{~m})$. It can live in the submontane zone $(400-1000 \mathrm{~m})$, but exclusively near cold springs. Flight period in spring and summer III-[X, but mainly V-VII.

Distribution: Pyrenean. Endemic to the Pyrenees where it occurs in the whole chain except its western extremity.

\subsection{Genus Pachyleuctra}

The genus Pachyleuctra contains three species strictly endemic to the Pyrenees : $P$. benllochi, $P$. bertrandi and $P$. ribauti (reinstated here as a valid species). It is characterised by the following features : in the male : paired sclerotized processes on 4 segments $(5,7,8,9) ; 10$ th tergum wide, pentagonal-shaped ; epiproct and paraprocts strongly reduced ; specillum well developed; ventral vesicle placed near the anterior margin of the 9th sternum. In the female : terga provided with a narrow median membranous strip while in the Leuctra genus this strip is generally much wider and occupies the whole dorsal face of the abdomen ; 10th segment forming a complete ring, not open ventrally. In the larva, abdominal segments 5 to 10 without membranous separation between terga and sterna (Berthélemy 1968, p. 176).

Determination of species is made on the basis of the shape of the tergal processes and genitalia in the male, and subgenital plate in the female.

\section{Pachyleuctra bertrandi Aubert, 1952 (Fig. 14 a-c)}

Pachyleuctra bertrandi Aubert, 1952 : 121-125 figs. 1-7 ; Berthélemy $1968: 175-179$ fig. $1,3,4$.

Type locality : France, Pyrénées-Orientales, brook of Etang de Puig Péric, $2400 \mathrm{~m}$

Etymology : Dedicated to the French entomologist Henri Bertrand, who collected the first specimens of this species.

Affinities : It is clearly separated from the two other $\mathrm{Pa}$ chyleuctra species in both sexes.

Male description: We give the complementary description of the male, since the abdomen extremity of the holotype was lost during study (Berthélemy 1968, p. 176) and no other male paratypes have been captured so far. The 10th tergum is provided with a short posterior expansion with its hind margin clearly concave, forming a V-shaped hollow (Fig. 14 a); the median membranous area is bean-shaped, without any dark patches. The epiproct is strongly reduced and hidden under the 10th tergum expansion. The paraprocts are not prolonged by styles. The specilla are slightly curved backwards in lateral view and provided with an oblique ring of strong setae just near the apex ; they end into a small inner hook (Fig. 14 b).

Ecology : Strongly orophilic, cold stenothermous species. $P$. bertrandi seems restricted to very high altitude springs, brooks and outlets of lakes (1900-2450 m). Its presence in lower watercourses remains doubtful and should be confirmed by the capture of adults (Puig 1984, Puig et al. 1987). Flight period in summer (VII).

Distribution : Eastem Pyrenees. It is endemic to a very restricted area in the eastern part of the Pyrenees (Aude and Pyrénées-Orientales) where it occurs in tributaries of the Aude, Têt and Ariège rivers (northern slope of the Pyrenees) and in the SËgre River (southern slope).

Pachyleuctra benllochi (Navás), 1917 (Fig. 14 d-f)

Leuctra benllochi, Navás 1917 : 6 fig. 3a.

Leuctra (Pachyleuctra) montana, Despax 1930a : $299 ; 1930 \mathrm{~b}: 144$ figs. 1-6 ; Leuctra benllochi, Navás Aubert $1948: 181$. 
Pachyleuctra benllochi, (Navás), Despax 1951 : 149 fig. 66a-c ; Aubert 1952 : 121-125 figs. 8-14 ; Berthélemy $1968: 175-179$ fig. 2 , 7.

Type locality : Spain, Pyrenees, San Juan del Yermo and Coma de Rubió (Lérida)

Etymology : Dedicated to Dr Benlloch, Bishop of La Seo de Urgel (Spain).

Affinities : Closely related to $P$. ribauti.

Ecology : Orophilic, rheophilic, cold stenothermous species, occurring mostly in high altitude brooks and torrents $(1200-2500 \mathrm{~m})$. It also inhabits the submontane zone (700$1200 \mathrm{~m}$ ), but close to cold springs. The adults emerge from March to July.

Distribution : Widespread throughout the Pyrenees.

Pachyleuctra ribauti Despax, 1930 (Fig. 14 g-h)

Pachyleuctra ribauti, Despax, 1930a : 301 ; Despax 1930b : 148 figs. 7-10; Despax 1951 : 151 figs. 66d-f.

Berthélemy (1966 p. 283) considered that the distinctive characters of $P$. ribauti were due to an hereditary malformation of $P$. benllochi concerning just a single population ; according, he has put $P$. ribauti in synonymy with $P$. benllochi.

However, we have discovered several other populations of $P$. ribauti in the mountainous region extending between Saint-Béat and Arbas (Haute-Garonne). In the Lez valley both taxa cohabit without producing intermediate forms, which indicates a genetic separation between them. Consequently, we propose the reinstatement of $P$. ribauti as a valid species.

Type locality : France, Haute-Garonne, Saint-Béat, Lez valley, $550 \mathrm{~m}$.

Etymology : Dedicated to Dr. Ribaut, Professor at the Toulouse Faculty of Medicine, who discovered this species.

Affinities : Closely related to $P$. benllochi from which it can be easily separated in the male by the shape of the tergal processes that ends in a blunt rounded apex (Fig. $14 \mathrm{~g}$ ) instead of a sharp point in $P$. benllochi (Fig. 14 a). The epiproct is similar in both two species (Fig. 14 e). The identification of the females should be confirmed by the capture of males since the position of the subgenital plate lobes is rather variable in the populations of $P$. benllochi during the mating period.

Ecology : Cold stenothermous, crenophilic species, living in the close surrounding of springs $(950-1300 \mathrm{~m})$. Flight period V-VII.

Distribution : Central Pyrenees. It is endemic to a very restricted region in the Haute-Garonne, living near the top of some pre-Pyrenean mountains : Cornudère massif $(1561 \mathrm{~m})$, Paloumère Pic (1608 m), Cagire Pic (1912 m), Escalette Pic $(1856 \mathrm{~m})$ and Puech $(1669 \mathrm{~m})$.

\section{Regional distribution}

The regional distribution of the 32 Pyrenean Leuctridae is given in Table 1.
The western Pyrenees have a high level of diversity (24 species). This hilly region (1000-2000 m a.s.1.) was never covered by the Quaternary glaciations, which could explain the presence of four relict elements that are not known elsewhere in the Pyrenees : Leuctra berthelemyi (holding an isolated position in the genus Leuctra), $L$. hexacanthoides, $L$. joani and $L$. clerguae. These micro-endemic species could survive in the low pre-Pyrenean mountains of Haute-Garonne (central Pyrenees) that have the same mild and humid climate, but their progression eastwards in the foothills is limited by large and deep valleys (Gave d'Ossau, Gave d'Oloron, Neste d'Aure ,...) that constitute a great obstacle for shortwinged species.

The western Pyrenees are also characterised by the presence of two "intrusive species" coming from the Cantabrian Cordillera and not extending eastwards in the Pyrenees : $L$. espanoli and $L$. maroccana.

The central Pyrenees are much higher (2000-3400 $\mathrm{m})$ and have a more continental climate. The fauna is also well diversified ( 25 species) and characterised by 2 micro endemic, strongly orophilic, species : Leuctra ariega and $L$. thomasi. In this highest part of the Pyrenean chain, the main natural barriers for the stoneflies are the deep valleys that were covered by huge glaciers during the Quaternary period (Garonne, Vicdessos, Ariège, Sègre, Têt). For example, Leuctra ariega and Protonemura culmenis (Zwick \& Vinçon, 1993) are isolated between the Vicdessos and Ariège valleys.

The eastern Pyrenees have a rather dry climate. The Leuctridae fauna is slightly less diversified than in the rest of the chain (19 species). One micro endemic Leuctridae species, Pachyleuctra bertrandi is isolated between the Ariège and Têt valleys, and another micro endemic stonefly, Protonemura canigolensis, is isolated between the Têt valley and the Mediterranean sea (Zwick \& Vinçon, 1993).

Moreover, some small calcareous massifs in front of the Pyrenean chain have also their own micro endemic species : Pachyleuctra ribauti Despax, 1930 (HauteGaronne) and Capnioneura aptera $\cdot$ Berthélemy, 1969 (Ariège). The high level of endemism in these small pre-Pyrenean massifs is linked to their geographic isolation and their unusual ecological conditions (humidity, calcareous substratum). These regions are also famous for their endemic Collembola fauna (Deharvenq in verbis).

The high level of micro endemism in the Pyrenean chain is also seen in other aquatic groups such as the Drusus and Rhyacophila (Trichoptera) (Sipahiler, $1992,1993 \& 2000$ ), with the following strongly res- 
tricted species : in the western Pyrenees : $D$. vinconi Sipahiler, 1992, D. rectus thibaulti Décamps, 1972 and $R$. eatoni McLachlan, 1879 ; in the central Pyrenees : $R$. rupta rupta McLchlan, 1879 ; in the eastern Pyrenees : $D$. marinettae Sipahiler, 1992, $R$. martynovi tetensis Sipahiler, 1993, $R$. rupta erkakanae Sipahiler, $1993, R$. vandeli Despax, 1933 and $R$. arties Sipahiler, 2000.

The southern slopes of the Pyrenees have a similar diversity to the northern slopes : Navarra (19 species), Aragon (13) and Cataluña (19).

\section{Types of distribution}

\subsection{Species endemic to the Pyrenees (13)}

Among the 13 Leuctridae endemic to the Pyrenees (Tab. 1), some species have a very restricted distribution area (micro endemic), while others are widespread throughout the whole Pyrenean chain (macro endemic).Two of them, though they extend slightly to the eastern part of the Cantabrian Cordillera, are considered as endemic Pyrenean species because their distribution in the Cantabrian Cordillera is very narrow and close to the Pyrenean chain. These 13 endemic species are listed below from east to west :

Micro endemic species (8 species) :

- Eastern Pyrenees : P. bertrandi

- Central Pyrenees : L. ariega, L. thomasi, P, ribauti

- Western Pyrenees : L. hexacanthoides, L. joani, $L$. berthelemyi, L. clerguae

Macro endemic species (5 species) :

- Eastern and central Pyrenees : L. garumna

- Central and western Pyrenees, and eastern extremity of the Cantabrian Cordillera : L. kempnyi, L. pseudocylindrica

- Whole Pyrenean chain : L. alticola, P. benllochi

\subsection{Pyrenean extensive species (4)}

These species called "Pyrenean extensive" by Aubert 1963, have their distribution area covering the whole Pyrenean chain, and they extend deeply in the neighbouring French or Spanish massifs :

- Pyrenees and Cantabrian Cordillera : L. lamellosa

- Pyrenees and northern part of the Iberian Peninsula : L. alosi

- French Massif-Central, Pyrenees and northern part of the Iberian Peninsula : $L$. despaxi and $L$. castillana.
11.3. Cantabrian species extending into the western part of the Pyrenees (1 species)

$$
\text { - L. espanoli }
$$

\subsection{West Mediterranean species (2)}

They have their distribution area extending in the western part of the Mediterranean Sea :

- Iberian Peninsula and Moroccan Rif : L. maroccana

- Iberian Peninsula and southern France : L. occitana

These two species belong to the same "occitana" group, which has a west Mediterranean distribution (Vinçon \& Pardo, 1998).

11.5. Species with wide distribution in Europe (12 species)

- Central-European species : L. albida, L. aurita and L. prima

- Central-north-European species : $L$. digitata

- Central-south-European species : L. leptogaster, $L$. major, L. mortoni and $L$. rauscheri

- European species : L. geniculata and $L$. inermis

- Eurosiberian species : $L$. fusca and $L$. hippopus

The Pyrenean Leuctridae communities are mainly composed of endemic species (41\%) and one endemic genus (Pachyleuctra), indicating a high level of isolation. Most of the endemic species $(62 \%)$ have a very narrow distribution area (micro endemism) and the limit of their distribution is related to geographic barriers or to ecological preferences. Among the 13 endemic species, 5 are strongly orophilic and live mainly between 1800 and $2550 \mathrm{~m}$ : Leuctra thomasi, L. ariega, L. alticola, Pachyleuctra bertrandi and $P$. benllochi $; 6$ are crenophilic species living exclusively in the close surrounding of the cold springs, mainly in the submontane zone (400-1500 m) : Leuctra joani, $L$. berthelemyi, L. clerguae, L. garumna, L. kempnyi and Pachyleuctra ribauti. Some of these crenophilic species are apterous or micropterous ( $L$. clerguae, $L$. joa$n i, L$. berthelemyi) or have a tendency to shortwingness (L. kempnyi, L. garumna).

\section{Acknowledgments}

We are very grateful to Dr. John E. Brittain (Oslo, Norway) for revising our English text, to Dr. Alain Thomas (Toulouse, France) for his bibliographical contribution and to Isabel Pardo (Vigo, Spain) and Jean Paul Reding (Neuchâtel, Switzerland) for their helpful comments.

\section{References}

Aubert J. 1948. - Plécoptères décrits par le R.P. L. Navás S.J. 1. Note sur quelques types du Musée de Barcelone. Mitt. Schweiz. ent. Ges., $10: 180-83$. 
Aubert J. 1952a. - Plécoptères décrits par le R.P. L. Navás S.J. 2. Note sur quelques types des Muséums de Barcelone et de:Paris. Mitt. Schweiz. ent. Ges., 25 : 239-241.

Aubert J. 1952b. - Plécoptères đécrits par le R.P. L. Navás S.J. 3. Les especes de la péninsule ibérique. Mitt. Schweiz. ent. Ges., $25: 242-250$

Aubert J. 1952c. - Plécoptères pyrénéens. Notes sur le genre $\mathrm{Pa}$ chyleuctra Despax et description de quelques larves nouvelles. Bull. soc. ent. France, 57 : 121-126.

Aubert J. 1953. - Plécoptères européens nouveaux. Mitt. Schweiz. ent. Ges., $26: 72-76$.

Aubert J. 1954a. - Contribution à l'étude du genre Leuctra Stephens et description de quelques espèces nouvelles de ce genre. Mitt. Schweiz. ent. Ges., 27 : 124-136.

Aubert J. 1956a. - Contribution à l'étude des Plécoptères d'Espagne. Mém. Soc. Vaudoise Sci. Nat., 11 : 209-276.

Aubert, J. 1956b. - Contribution à l'étude des Plécoptères d'Afrique du Nord. Mitt. Schweiz. ent. Ges., 29 : 419-436.

Aubert J. 1957. - Les Leuctra du groupe de inermis Kempny et quelques espèces inermes isolées (Plécoptères Leuctridae). Mitt. Schweiz. ent. Ges., $30: 285-312$.

Aubert J. 1959. - Plecoptera. Insecta Helvetica, Fauna, 1 : 1-140.

Aubert J. 1962. - Quelques Leuctra nouvelles pour l'Europe (Plécoptères Leuctridae). Mitt. Schweiz. ent. Ges., 35 : 155-169.

Aubert J. 1962. - Les Plécoptères de la péninsule ibérique. EOS Rev. espan. entomol., $39: 23-107$

Berthélemy C. 1966 . - Recherches écologiques et biogéographiques sur les Plécoptères et Coléoptères d'eau courante ( $H y-$ draenae et Elminthidae) des Pyrénées. Ann. Limnol., 2 : 227-458.

Berthélemy C. 1968. - Contribution à la connaissance des Leuctridae (Plecoptera). Ann. Limnol., $1:$ 257-276

Berthélemy C. 1969. - Les Capnioneura des Pyrénées (Plecoptera). Annls Limnol., $5: 25-47$.

Berthélemy C. \& Whytton da Terra L.S.1980. — Plécoptères du Portugal (Insecta). Ann. Limnol., 16:159-182.

Brinck P. 1949. - Studies on Swedish Stoneflies (Plecoptera). Opusc. Ent. Suppl. 11, XII+250.

Consiglio C. 1957. - Tyrrhenoleuctra Nomen Novum. Boll. Soc. Ent. Ital., $87: 1-2$.

Despax R. 1929a. - Description sommaire d'un sous-genre nouveau et de deux espéces nouvelles du genre Leuctra Steph. (Plecoptera). Bull. Soc. Ent. France, 1929 : 298-301.

Despax R. 1929b. - Plécoptères pyrénéens. II. Etude et description de quelques formes du genre Leuctra Steph. Bull. Soc. Hist. Nat. Toulouse, 58 : 165-178.

Despax R. 1930a. - Plécoptères pyrénéens. III. Etude des espèces du genre Leuctra Steph. appartenant au sous-genre Pachyleuctra Desp. Bull. Soc. Hist. Nat. Toulouse, 59 : 139-151.

Despax R. 1930b. - Leuctra occitana nov. sp. Plécoptère nouveau de la région Toulousaine. Bull. Soc. Hist. Nat. Toulouse, 59 : 171-176.

Despax R. 1931. - Plécoptères Pyrénees. IV. Leuctra cincta Mort. et Leuctra pseudocylindrica Desp. Bull. Soc. Hist. Nat. Toulouse, $61: 156-160$.

Despax R. 1933. - Plécoptères pyrénéens. VII. Leuctra inermis Kempny et espèces affines. Bull. Soc. Hist. Nat. Toulouse, 65 : 628-630.

Despax R. 1940. - Plecoptères de la Grande Chartreuse. Bull. Soc. Hist. Nat. Toulouse, 75 : 296-299.

Despax R. 1951a. - Plécoptères. Faune de France, 55 : 1-280.

Despax R. 1951b. — Ordre des Plécoptères. In : Grassé P.P. Traité de Zoologie, IX : 557- 586
Illies J. 1955. - Steinfliegen oder Plecoptera. Die Tierwelt Deutschlands, $43: 1-150$.

Illies J. 1966. - Katalog der rezenten Plecoptera. Das Tierreich, $82: \mathrm{XXX}+632$.

Kempny P. 1898. - Zur Kenntnis der Plecopteren. II. Neue und ungenuigend bekannte Leuctra Arten. I. Teil. Verh. kk. zool. bot. Ges. Wien, $48:$ 213-221.

Kempny P. 1899a. - Zur Kenntnis der Plecopteren. II. Neue und ungenïgend bekannte Leuctra Arten. II. Teil Verh. kk. zool. bot. Ges. Wien, 49 : 9-15.

Kempny P. 1899b. - Zur Kenntnis der Plecopteren. II. Neue und ungenügend bekannte Leuctra Arten. III. Teil Verh. kk. zool. bot. Ges. Wien, $49: 269-278$.

Kempny P. 1900. - Beitrag zur Perliden- und Trichopteren-Fauna Südtirols. Verh. kk. zool. bot. Ges. Wien, 50 : 254-258.

Kis B. 1974. - Plecoptera. Fauna Rep. Soc, Romania, Insecta. Acad. Rep. Soc. Romania, 8 (7) : 1-273.

Lillehammer A. 1986. - Taxonomic differences between populations of Leuctra hippopus Kempny (Plecoptera) in Norway. Fauna. norv. Ser. $B, 33: 27-32$.

Lillehammer A. 1988. - Stoneflies (Plecoptera) of Fennoscandia and Denmark. Fauna ent. scand., $21: 1-165$.

MacLachlan R. 1864. - Note on the manner in which the females of the genus Leuctra carry their eggs. Entomologist's mon. Mag., 1 : 216

Membiela P. 1989. - Two New Species of Leuctra of the Iberian Peninsula (Insecta, Plecoptera). Aquatic Insects, 11 : 81-87.

Morton K. J. 1929. - Notes on the genus Leuctra with description of two new species, and on the genus Capnia including a species new to the British fauna. Mont. mo. Mag., 65 : 128-134.

Mosely M.E. 1930. - Plecoptera. In : New European Trichoptera and Plecoptera. Trans. Ent. Soc., 78 : 249-253.

Mosely M. E. 1932. - A revision of the European species of the genus Leuctra. Ann. \& Mag. N. Hist, $10: 1-41$.

Navás L. 1917. - Plecopteros. In : Neuropteros nuevos o poco conocidos. Mem. R. Acad. Cienc. y Artes Barcelona, 13, 7 : (5-8) $157-160$

Navás L. 1919. - Orden Plecópteros. In : Excursiones entomologicas por Cataluña durante el verano de 1918 . Mem. R. Acad. Cienc. y Artes Barcelona, 15, $5: 190-192$.

Olivier G. 1811. - Némoure in Encyclopédie méthodique, Histoire naturelle, Insectes., $8: 184-186$.

Pardo I. \& Vinçon G. 1995. - Contribution to the knowledge of Pyrenean stoneflies : Leuctra ariega sp. n. (Insecta Plecoptera). Aquatic Insects, $17: 71-75$.

Puig M.A. 1984. - Distribution and ecology of the stoneflies (Plecoptera) in Catalonian rivers (NE-Spain). Ann. Limnol., 20 : 75-80.

Puig M.A., González G. \& Recasens L. 1987. - Modelos de distribucion de Plecopteros, Efemeropteros, Tricopteros y Simulidos en el Río Ter. Limnetica, $3:$ 125-132.

Puig M.A., González G. \& Soriano O. 1984. - Introducción al estudio de las comunidades macrobentonicas de los ríos asturianos: Efemerópteros, Plecópteros, Tricópteros, Simulidos y Quironómidos. Limnetica, 1 : 188-196.

Ravizza C. \& Vinçon G., 1998. - Les Leuctridés (Plecoptera, Leuctridae) des Alpes. Mitt. Schweiz. ent. Ges., $71: 285-342$.

Rauser J. 1956. - K poznání rodu Leuctra Stephens ve Slezsku. Spisy prir. fak. MU, $372: 1-54$.

Ricker W.E. 1996. - Stonefly names from classical times. Perla, $14: 3743$

Sanchez-Ortega A. \& Alba-Tercedor J. 1987. - Lista faunistica y bibliografica de los Plecopteros de la Peninsula Ibérica. Asociacion Española de Limnologia, 4 : 1-133. 
Sanchez-Ortega, A. \& Alba-Tercedor J. 1990. - Los Plecópteros de Sierra Nevada (Granada España). Zoologica baetica, 1 : 77-146.

Sipahiler F. 1992. - Four new species of Drusinae from Spain and France (Insecta, Trichoptera, Limnephilidae). Spixiana, 15: 285-291.

Sipahiler F. 1992. - Three new Rhyacophila subspecies from France (Insecta, Trichoptera, Rhyacophilidae), Spixiana, $16: 43-47$.

Sipahiler F. 2000. - New Rhyacophila (Trichoptera, Rhyacophilidae) Species from France and Spain. Aquatic Insects, 22 : 138-147.

Tierno de Figueroa J.M. \& Sánchez-Ortega A. 1995. - Nuevas citas de Plecópteros (Insecta, Plecoptera) en el Pirineo español. Boln. Asoc. esp. Ent., $19:$ 194-195.

Tiemo de Figueroa J.M. \& Sánchez-Ortega A. 1995. - Confirmación de la presencia de Leuctra alticola Despax, 1992 en España (Plecoptera : Leuctridae). Boln. Asoc. esp. Ent., $20: 254$.
Vinçon G. 1996. - Les Plécoptères des Alpes françaises. Mitt. Schweiz. ent. Ges., 69 : 61-75.

Vinçon G. \& Pardo I. 1994. - Contribution to the knowledge of Pyrenean stoneflies : Leuctra joani sp. $\mathbf{n}$. and $L$. clerguae sp. n. (Insecta Plecoptera). Aquatic Insects, $16: 205-212$.

Vinçon G. \& Pardo I. 1998. - Three New Leuctra Species from Tunisia (Plecoptera : Leuctridae). Aquatic Insects, 2 : 109-123.

Vinçon G. \& Ravizza C. 1996. - Two new Leuctra in the inermis group : $L$. garumna from the Pyrenees and $L$. ameliae from the Western Alps (Insecta Plecoptera). Aquatic Insects, 18 : 149-156.

Zwick P. 1973. - Insecta Plecoptera, Phylogenetisches System und Katalog. Das Tierreich Berlin, 94 : 465 pp.

Zwick P. \& Vinçon G. 1993. - Contribution to the knowledge of Pyrenean stoneflies (Insecta Plecoptera). Ann. Limnol., 29 : 47-57. 